Research

\title{
Elevation of circulating serotonin improves calcium dynamics in the peripartum dairy cow
}

\author{
Samantha R Weaver', Austin P Prichard', Elizabeth L Endres', Stefanie A Newhouse', \\ Tonia L Peters', Peter M Crump², Matthew S Akins³, Thomas D Crenshaw², \\ Rupert M Bruckmaier ${ }^{4}$ and Laura L Hernandez' ${ }^{1}$
}

1Department of Dairy Science, University of Wisconsin-Madison, Madison, Wisconsin, USA 2Department of Animal Sciences, University of Wisconsin-Madison, Madison, Wisconsin, USA 3Department of Dairy Science, University of Wisconsin-Madison, Marshfield, Wisconsin, USA

${ }^{4}$ Department of Veterinary Physiology, Vetsuisse Faculty, University of Bern, Bern, Switzerland

Correspondence should be addressed to L L Hernandez Email Ilhernandez@wisc.edu

\begin{abstract}
Hypocalcemia is a metabolic disorder that affects dairy cows during the transition from pregnancy to lactation. Twelve multiparous Holstein cows and twelve multiparous Jersey cows were intravenously infused daily for approximately 7 days prepartum with either saline or $1.0 \mathrm{mg} / \mathrm{kg}$ bodyweight of the immediate precursor to serotonin synthesis, 5 hydroxy-L-tryptophan (5-HTP). On infusion days, blood was collected before, after, and at 2, 4, and $8 \mathrm{~h}$ postinfusion. Blood and urine were collected daily before the infusion period, for 14 days postpartum and on day 30 postpartum. Milk was collected daily during the postpartum period. Feed intake and milk yield were unaffected by 5-HTP infusion postpartum. Cows infused with 5-HTP had elevated circulating serotonin concentrations prepartum. Infusion with 5-HTP induced a transient hypocalcemia in Jersey cows prepartum, but not in any other treatment. Holstein cows infused with saline had the highest milk calcium on the day of and day after parturition. Postpartum, circulating total calcium tended to be elevated, and urine deoxypyridinoline (DPD) concentrations were elevated in Holstein cows infused with 5-HTP. Overall, Jerseys had higher urine DPD concentrations postpartum when compared with Holsteins. Taken together, these data warrant further investigation of the potential therapeutic benefit of 5-HTP administration prepartum for prevention of hypocalcemia. Further research should focus on delineation of mechanisms associated with 5-HTP infusion that control calcium homeostasis during the peripartum period in Holstein and Jersey cows.
\end{abstract}
Key Words
- serotonin
- calcium
- peripartum period
- dairy cow

Journal of Endocrinology (2016) 230, 105-123

\section{Introduction}

Hypocalcemia is a costly and potentially fatal disease that affects dairy cows most prominently during the transition from pregnancy to lactation. During these 3 weeks preand postpartum, the dairy cow is predisposed to major metabolic changes that put significant demands on both energy and calcium reserves. Calcium, the major mineral in milk, is needed for bone formation in the growing neonate. Dairy cows will produce anywhere

Published by Bioscientifica Ltd 
from 1 to $20 \mathrm{~kg}$ of colostrum. Depending on parity, milk production will increase by approximately $10 \mathrm{~kg}$ in the first 5 days postpartum (Kessler et al. 2014). With such a dramatic increase in milk production, enormous demands are exerted on body calcium reserves for transfer into milk. The early lactation dairy cow is often incapable of replacing circulating calcium stores, resulting in hypocalcemia.

Clinical hypocalcemia (less than $1.4 \mathrm{mmol} / \mathrm{L}$ total circulating calcium) has a prevalence of between 5 and $10 \%$ in the United States dairy cow population, while the subclinical form of the disease $(1.4-2.0 \mathrm{mmol} / \mathrm{L})$ occurs at a greater (25-50\%) incidence (Goff 2008, Reinhardt et al. 2011). Hypocalcemia is considered a 'gateway disease'. Following parturition, the demand for calcium is typically the first major metabolic challenge, making the cow vulnerable to a host of further negative health outcomes. For example, calcium is required for both smooth muscle contraction and proper immune function, in addition to many intracellular functions (Martinez et al. 2014). In the dairy cow, smooth muscle contraction is responsible for rumen and gut motility as well as uterine and teat sphincter contraction (Kimura et al. 2006, Goff 2008). Dysregulation of these physiological functions as a result of low calcium leads to many other common transition period diseases, including ketosis and fatty liver, displaced abomasum, dystocia, metritis, and mastitis (Kimura et al. 2006, Goff 2008, Martín-Tereso \& Verstegen 2011, Chapinal et al. 2011). In addition, subclinical hypocalcemia specifically has been linked to greater risk of fever, as well as decreased pregnancy rates and longer intervals to pregnancy (Martinez et al. 2012). Overall, hypocalcemia is considered a major health event in the life of the cow, as it predisposes her to diseases in current and future lactation cycles. This is of particular concern in older cows of all breeds and all Jersey cows, both of which have an increased predisposition to hypocalcemia (Oetzel et al. 1988, Lean et al. 2006). Limited research is available to establish why Jersey cows have an increased incidence of hypocalcemia. Two main explanations have focused on either the increased milk production per unit of body weight or the potential reduced concentration of vitamin D receptors in Jersey cows versus Holstein cows (Oetzel et al. 1988, Goff et al. 1995). A gap in understanding of the breed-dependent mechanisms regulating hypocalcemia still exists. Additionally, despite the economic and animal health ramifications of hypocalcemia, limited preventative options are available for application by the dairy industry. The limitation in preventative applications is further compromised by the lack of a cost-effective, on-farm method available to measure blood calcium concentrations in individual cows (McArt $\&$ Oetzel 2015). Broader preventative strategies against hypocalcemia are needed. We propose that administering a serotonin precursor, 5-hydroxy-L-tryptophan (5-HTP), and subsequently increasing circulating serotonin levels during the immediate prepartum phase, may offer a powerful preventative strategy against postpartum hypocalcemia.

Serotonin is an evolutionarily conserved monoamine, signaling via approximately 15 receptor isoforms throughout the mammalian body to exert a wide range of physiological effects (Matsuda et al. 2004, Hannon \& Hoyer 2008). Serotonin is synthesized in a two-step pathway, with the formation of 5-HTP being the rate-limiting step (Wang et al. 2002). During lactation, non-neuronal serotonin acts as a homeostatic regulator of the mammary gland in rodents, dairy cows, humans, and likely many other species (Stull et al. 2007, Hernandez et al. 2012a, Horseman \& Hernandez 2014, Laporta et al. 2015). Importantly, serotonin modulates calcium homeostasis in rodent models (Hernandez et al. 2012b, Laporta et al. 2013a, 2014a) through a pathway involving the mammary-derived molecule parathyroid hormone-related protein (PTHrP). The PTHrP hormone has a definite role in calcium modulation during lactation (Wysolmerski et al. 1995, Wysolmerski 2010, Hernandez et al. 2012b). Despite the well-established relationship between serotonin and calcium homeostasis in various rodent models, limited research has been reported in dairy cows, even with their susceptibility to calcium insults at parturition. To date, our lab has demonstrated that manipulation of the serotonergic system impacts calcium regulation in latelactation, nonpregnant, homeostatically stable dairy cows (Laporta et al. 2015). Additionally, calcium and serotonin are positively correlated on the day of parturition in both Holstein and Jersey breeds (Laporta et al. 2013b, Moore et al. 2015). We have begun to establish a model in which a transient hypocalcemia provokes release of mammaryderived PTHrP, which can then act on bone to release calcium for transfer into milk: a process that is regulated by serotonin (Laporta et al. 2014b). However, the impacts of serotonin on calcium homeostasis in Holstein and Jersey cows during the transition period, when dairy cows are most susceptible to hypocalcemia, has not been established.

The objective of this study was to determine the effects of treatment with 5-HTP prepartum on the regulation of calcium homeostasis in transition dairy cows. We also aimed to establish any differential responses between

Published by Bioscientifica Ltd. 
Holstein cows and Jersey cows to 5-HTP administration. We hypothesized that treatment with 5-HTP prepartum would positively impact calcium homeostasis postpartum, and thus reduce the incidence of hypocalcemia in Holstein and Jersey cows transitioning from pregnancy to lactation. Given the predisposition of Jersey cows to hypocalcemia, we hypothesized that treatment with 5 -HTP would induce more dramatic responses in terms of calcium homeostasis in Jersey cows compared with Holstein cows.

\section{Materials and methods}

\section{Animals and experimental design}

All of the experiments were performed under protocols approved by the Animal Care and Use Committee at the University of Wisconsin-Madison (Protocol number A01521). The trial was conducted from May of 2014 through March of 2015. Approximately, 3 weeks before their date of expected parturition, 12 multiparous Holstein (average lactation number $3.67 \pm 0.43$ ) and 12 multiparous Jersey (average lactation number $2.83 \pm 0.37$ ) dairy cows were transported to the Dairy Cattle Center at the University of Wisconsin-Madison. Holstein cows and Jersey cows were enrolled simultaneously. Approximately 1 week was allowed for cows to acclimatize to the barn, which uses tie-stall housing. Prepartum, cows were fed a low-energy, high-fiber diet which relies on the fact that straw and corn silage are generally lower in potassium content, and thus help to control the dietary cationanion difference (DCAD) without supplemental anionic salt addition (Drackley \& Guretzky 2007). At parturition, cows were switched to a diet that was formulated for lactating cows. Feed samples were collected weekly, and monthly composites were subsequently dried, ground, and analyzed for nutrient composition (Dairyland Laboratories, Arcadia, WI, USA). Ingredient and nutrient composition of the dry, pregnant, and lactating cow diets are shown in Table 1.

Approximately, 7 days before the predicted date of parturition, cows were weighed and subsequently infused daily at approximately $0800 \mathrm{~h}$ with either $1 \mathrm{~L}$ of saline or $1 \mathrm{~L}$ of saline containing $1 \mathrm{mg} / \mathrm{kg}$ bodyweight of 5 -HTP (Sigma-Aldrich). The dose of $1 \mathrm{mg} 5$-HTP/kg bodyweight was based on results of a previous experiment designed to determine the optimum dose of 5-HTP to administer to dairy cows (Laporta et al. 2015). The final treatment groups were Holstein cows infused with saline (H CON; $n=6$ ), Holstein cows infused with saline +5-HTP
Table 1 Nutrient composition in dry and lactating cow diets.

\begin{tabular}{|c|c|c|}
\hline & Dry cow & Lactating cow \\
\hline \multicolumn{3}{|l|}{ Nutrients } \\
\hline Dry matter (\% as fed) & 43.4 & 53.4 \\
\hline$C P(\%$ of $D M)$ & 12.69 & 17.06 \\
\hline aNDF ( $\%$ of DM) & 45.95 & 34.9 \\
\hline Lignin (\% of DM) & 3.45 & 4.15 \\
\hline NFC ( $\%$ of DM) & 33.7 & 37.92 \\
\hline Ash ( $\%$ of DM) & 7.32 & 7.32 \\
\hline $\mathrm{NE}_{\mathrm{M}}(\mathrm{Mcal} / \mathrm{kg})$ & 1.49 & 1.68 \\
\hline $\mathrm{NE}_{\mathrm{L}}(\mathrm{Mcal} / \mathrm{kg})$ & 1.48 & 1.58 \\
\hline \multicolumn{3}{|l|}{ Minerals (\% DM) } \\
\hline Calcium & 0.75 & 0.97 \\
\hline Phosphorous & 0.38 & 0.42 \\
\hline Magnesium & 0.35 & 0.37 \\
\hline Potassium & 1.13 & 1.48 \\
\hline Sulfur & 0.25 & 0.22 \\
\hline Sodium & 0.15 & 0.45 \\
\hline Chloride & 0.33 & 0.45 \\
\hline DCAD (mEq/100 g DM) & 9.93 & 30.95 \\
\hline
\end{tabular}

aNDF, amylase neutral detergent fiber; $C P$, crude protein; $D C A D$ $(\mathrm{mEq} / 100 \mathrm{~g})$, dietary cation-anion difference; $\mathrm{NE}_{\mathrm{L}}$ (Mcal $\left./ \mathrm{kg}\right)$, net energy available for lactation; $\mathrm{NE}_{\mathrm{M}}$ (Mcal $/ \mathrm{kg}$ ), net energy available for maintenance; NFC, nonfiber carbohydrates.

(H 5-HTP; $n=6$ ), Jersey cows infused with saline (J CON; $n=6$ ), and Jersey cows infused with saline +5 -HTP (J 5-HTP; $n=6$ ). The final doses of 5-HTP administered in grams ranged from a total of 0.75 to $0.85 \mathrm{~g}$ in $\mathrm{H} 5-\mathrm{HTP}$ and from 0.47 to $0.55 \mathrm{~g}$ in J 5-HTP. Holstein cows were infused for $5.67 \pm 0.78$ days and Jersey cows were infused for $8.67 \pm 1.53$ days prepartum leading up to the day of parturition $(P>0.05$ for number of days infused between Holstein cows and Jersey cows). All cows were infused for at least 3 days with the exception of one H CON that was infused for 1 day and one J 5-HTP that was infused for 2 days. Each infusion was completed over the course of approximately $45 \mathrm{~min}$. Heart rate (HR), respiration rate (RR), and rectal temperature (RT) were recorded for each cow before the infusion began, every $15 \mathrm{~min}$ of the infusion, and at the end of the infusion to monitor the cow health response to the infusion. Frequency of defecation and stool consistency (with $1=$ solid stool through $4=$ diarrhea) was also recorded throughout the infusion (Laporta et al. 2015). Cows were also weighed on day 7 of lactation. Blood, urine, and milk samples were collected daily, and daily feed intake was recorded from the date of enrollment approximately 2 weeks before parturition through 14 days into lactation and on day 30 of lactation, while milk yield was recorded from the date of parturition through 14 days of lactation and on day 30 of lactation using DairyComp 305 records from morning and evening milkings.

Published by Bioscientifica Ltd. 


\section{Sample collection}

Approximately, 7 days before the predicted parturition date, a jugular catheter was inserted in each cow (Abbocath-T Subclavian I.V. $14 \mathrm{~g} \times 5 \quad 1 / 2$ " Catheter, Hospira, Lake Forest, IL, USA). Catheters were placed under an i.v. sedative and analgesic cocktail $(0.02 \mathrm{mg} / \mathrm{kg}$ butorphanol, Fort Dodge Laboratories (Fort Dodge, IA, USA) and $0.02 \mathrm{mg} / \mathrm{kg}$ xylazine, AnaSed (Shenandoah, IA, USA)). Before insertion, the surgical site was shaved and scrubbed with betadine surgical scrub (Veterinary Purdue Products, Stamford, CT, USA) and 70\% ethanol. Following insertion, catheters were sutured to the skin, and the cow's neck was wrapped with $7.6 \mathrm{~cm}$ Elastikon Elastic Tape (Johnson \& Johnson) to secure the catheters in place. Every $8 \mathrm{~h}$, catheters were flushed with $10 \mathrm{~mL}$ sterile saline solution containing $10 \mathrm{IU} / \mathrm{mL}$ heparin (Sagent Pharmaceuticals, Schaumburg, IL, USA).

Blood samples were collected daily before the days of infusion from the coccygeal vein. On infusion days, whole blood samples were taken from the jugular catheter before the infusion, immediately following infusion, and at 2,4 , and $8 \mathrm{~h}$ postinfusion. On the day of parturition, the jugular catheter was removed and subsequent blood samples were taken from the coccygeal vein. Blood samples collected on the day of parturition were taken as close to parturition as possible, but within at least $2 \mathrm{~h}$ after parturition. To isolate the serum fraction from blood, $10 \mathrm{~mL}$ BD Vaccutainer Serum Plus Tubes (367820, BD, Franklin Lakes, NJ, USA) were used. For the plasma fraction, blood was collected into Lithium Heparin 158 USP Units Plus Blood Collection Tubes (367880, BD, Franklin Lakes, NJ, USA). Following centrifugation at $3000 \mathrm{~g}$ for $20 \mathrm{~min}$ at $4^{\circ} \mathrm{C}$, the serum or plasma fractions were collected and stored at $-80^{\circ} \mathrm{C}$ until analysis.

Urine samples were taken daily. Urine was obtained by gently massaging the area between the udder and the vulva and collecting mid-stream samples in $5 \mathrm{~mL}$ Eppendorf tubes. All urine samples were stored at $-20^{\circ} \mathrm{C}$ until analysis. Milk samples were collected each morning for $14 \mathrm{~d}$ after parturition into sterile Eppendorf tubes and stored at $-20^{\circ} \mathrm{C}$.

\section{Sample laboratory analyses}

For all assays performed, a quality control (QC) was analyzed on each plate to assure the integrity of the assay. Serotonin concentrations were analyzed in serum via a Serotonin Enzyme Immunoassay (EIA) Kit following the manufacturer's instructions (IM1749, Immunotech, Beckman Coulter, Marseille Cedex, 9, France). All serum samples were diluted 1:100 in order to fit within the range of the assay's standard curve. The intra- and interassay coefficient of variation (CV) were 7.9 and 15.3\%, respectively. Total calcium in serum was determined using a colorimetric calcium assay kit (no. 700550, Cayman Chemical). The intra-assay CV for the serum calcium was $3.9 \%$ and the interassay CV was $7.8 \%$. Total milk calcium was measured using atomic absorption spectrophotometry (Perkin-Elmer Model 2280, Perkin-Elmer), after digestion with nitric and perchloric acid (4:2 vol/vol) as described previously (Laporta et al. 2015). To assure accuracy, one milk sample in each digest was spiked with a known quantity of calcium and the percentage of calcium recovery was calculated. The average calcium recovery across all digests was $96.6 \%$.

Prolactin was measured in plasma by radioimmunoassay as described previously by Bruckmaier and coworkers (1992). The intra-assay CV was $2.3 \%$ and the interassay was $8.4 \%$. Deoxypyridinoline (DPD) was measured in urine using an enzyme immunoassay (DPD MicroVue Bone Health, ALPCO, Salem, NH, USA). All samples were diluted 1:10 to fit within the standard curve. The intra-assay CV was $3.4 \%$ and the interassay $\mathrm{CV}$ was $8.8 \%$. To account for urine volume, DPD concentrations were corrected for creatinine concentrations in the urine. Urine creatinine concentration was determined using a colorimetric assay per the manufacturer's instructions (DICT-500, QuantiChrom Creatinine Assay Kit, BioAssay Systems, Hayward, CA, USA). For urine creatinine measurements, the intra-assay CV was $3.6 \%$ and the interassay $\mathrm{CV}$ was $8.8 \%$.

\section{Statistical analysis}

Analysis of the data in this study was completed using a linear mixed model with repeated measures using SAS software (version 9.3; SAS Institute Inc, Cary, NC, USA). Prepartum and postpartum time periods as well as within-treatment or within-breed effects were analyzed separately. The model used was $\mathrm{Y}=\mathrm{T}+\mathrm{B}+\mathrm{T}^{*} \mathrm{~B}+\operatorname{Cow}(\mathrm{T})+\mathrm{D}+\mathrm{D}^{*} \mathrm{~T}+\mathrm{D}^{*} \mathrm{~B}+\mathrm{D}^{*} \mathrm{~T}^{*} \mathrm{~B}+\mathrm{e}$, where $T$ was the fixed effect of treatment with saline or 5-HTP, B was the fixed effect of the breed (Holstein or Jersey), and D was the fixed effect of the day relative to parturition (DRP), with parturition as day (0). The random effect of Cow within treatment was considered the error term for all effects that did not include the day (D) effect. In order to account for autocorrelated errors due to repeated measurements on the same experimental unit, $\operatorname{Cow}(\mathrm{T})$, an $\operatorname{ar}(1)$ error structure was used within the SAS MIXED procedure. The residuals from the model were analyzed with a normality test,

Published by Bioscientifica Ltd 
and when the normality assumption failed, the ranks of the data were analyzed in a nonparametric matter. Each metabolite was evaluated for extreme influential data points and outliers, which were removed when identified. In the analyses of calcium and serotonin, a covariate correction was necessary. The covariate used was a baseline average of three daily blood samples taken before any treatment applied to the cow. When relevant, particular preplanned days relative to parturition were isolated and compared using the same model stated above. Manure severity index was calculated by summing the manure scores across days (with $1=$ solid stool through $4=$ very loose stool) and then analyzing the fixed effects of treatment, breed, and the interaction. In the reporting of HR, RR, RT, and manure severity and frequency, an average of 7 days of infusion were included in the analysis. For all analyses, differences between means were considered significant at $P<0.05$ and were considered a tendency when $0.05<P<0.10$. All values are reported as LS mean \pm S.E.M.

\section{Results}

\section{Cow health and bodyweight were not affected by 5-HTP infusion}

In a previous study of late-lactation Holsteins, 5-HTP was determined to be safe for i.v. administration at $1.0 \mathrm{mg} / \mathrm{kg}$ (Laporta et al. 2015). Using the same cow health parameters of HR, RR, and RT in the current study, 5-HTP was determined safe to administer to both Holstein and Jersey cows during the transition period. Neither treatment nor breed altered any cow health trait throughout the course of i.v. infusion of 5-HTP $(P>0.05)$. Both Holstein and Jersey cows given 5-HTP produced a looser stool throughout the infusion period when compared with saline-infused cows $(P<0.0001)$. All cows administered 5-HTP defecated more frequently than saline-infused cows $(P<0.0001)$. Breed did not affect defecation frequency or manure severity index $(P>0.05)$.

Treatment did not affect bodyweights pre- or postpartum in either Holstein or Jersey cows $(P>0.05)$, but cows weighed less postpartum relative to prepartum $(P<0.006)$ and Jerseys weighed less than Holsteins $(P<0.0001)$. The average bodyweights prepartum were $822 \pm 20,824 \pm 24,552 \pm 23$, and $511 \pm 15 \mathrm{~kg}$ for $\mathrm{H} \mathrm{CON}$, H 5-HTP, J CON, and J 5-HTP, respectively. The average bodyweights 7 days postpartum were $775 \pm 22,749 \pm 37$, $508 \pm 15$, and $493 \pm 15 \mathrm{~kg}$ for H CON, H 5 -HTP, J CON, and J 5-HTP, respectively.
Overall disease incidence was recorded throughout the experiment. Of the 24 cows enrolled in our study, two H CON, two H 5-HTP, three J CON, and two J 5-HTP cows were treated for ketosis. With respect to mastitis, one H CON, three H 5-HTP, four J CON, and one J 5-HTP cow had mastitis. One H 5-HTP cow had a retained placenta. Finally, two H CON, two J CON, and one J 5-HTP cow required i.v. calcium administration after parturition due to clinical symptoms of hypocalcemia.

\section{Feed intake and milk yield are not affected by 5-HTP infusion postpartum}

Overall, feed intake was dynamic in response to 5-HTP infusion in both breeds (Fig. 1A). Prepartum, H CON tended to eat more than H 5-HTP $(P=0.06)$, significantly so on the 2 days before parturition $(P \leq 0.05)$. There was also a significant effect of DRP on feed intake in the Holstein cows before parturition $(P<0.0001)$, but no treatment and time interaction $(P>0.05$; Fig. 1B). Postpartum, DRP had an effect $(P<0.0001)$ on feed intake in Holstein cows, but there was no treatment effect or treatment and DRP interaction $(P>0.05$; Fig. 1C). Prepartum in Jersey cows, there was a treatment and time interaction $(P=0.009)$ and an effect of DRP $(P=0.002)$, with all cows eating less as they approached parturition and J 5-HTP cows eating less than J CON cows on 4 days before parturition $(P=0.02)$. There was no effect of treatment alone on Jersey cows' feed intake prepartum $(P>0.05$; Fig. 1D). Postpartum, Jersey cows ate more throughout the lactation $(P<0.0001)$, but there was no effect of treatment and no treatment and DRP interaction $(P>0.05$; Fig. 1E). As anticipated, $\mathrm{J}$ CON cows ate less than $\mathrm{H}$ CON cows both prepartum $(P=0.004)$ and postpartum $(P=0.02)$, and there was an effect of DRP both pre- and postpartum $(P<0.0001$; Fig. 1F and G). Similarly, J 5-HTP ate less than H 5-HTP prepartum $(P=0.009$; Fig. $1 \mathrm{H})$, but ate a similar amount postpartum $(P>0.05)$, eating less only on days 11,12 , and 13 of lactation $(P \leq 0.05$; Fig. 1I).

Milk yield increased throughout lactation in all treatment groups (Fig. 2A). Within Holstein and Jersey cows, there was no treatment effect $(P>0.05)$, except for on the day of parturition, when J CON gave more milk than J 5-HTP ( $P=0.03$; Fig. $2 \mathrm{~B}$ and $\mathrm{C})$. Among all cows that received the saline infusion, $\mathrm{H}$ CON cows had significantly higher milk yields than J CON cows on all days of lactation $(P \leq 0.002)$ besides the day of parturition $(P>0.05)$ and day $1(P=0.07$; Fig. $2 \mathrm{D})$. The same phenomenon was seen in the 5-HTP-infused cows,

Published by Bioscientifica Ltd 

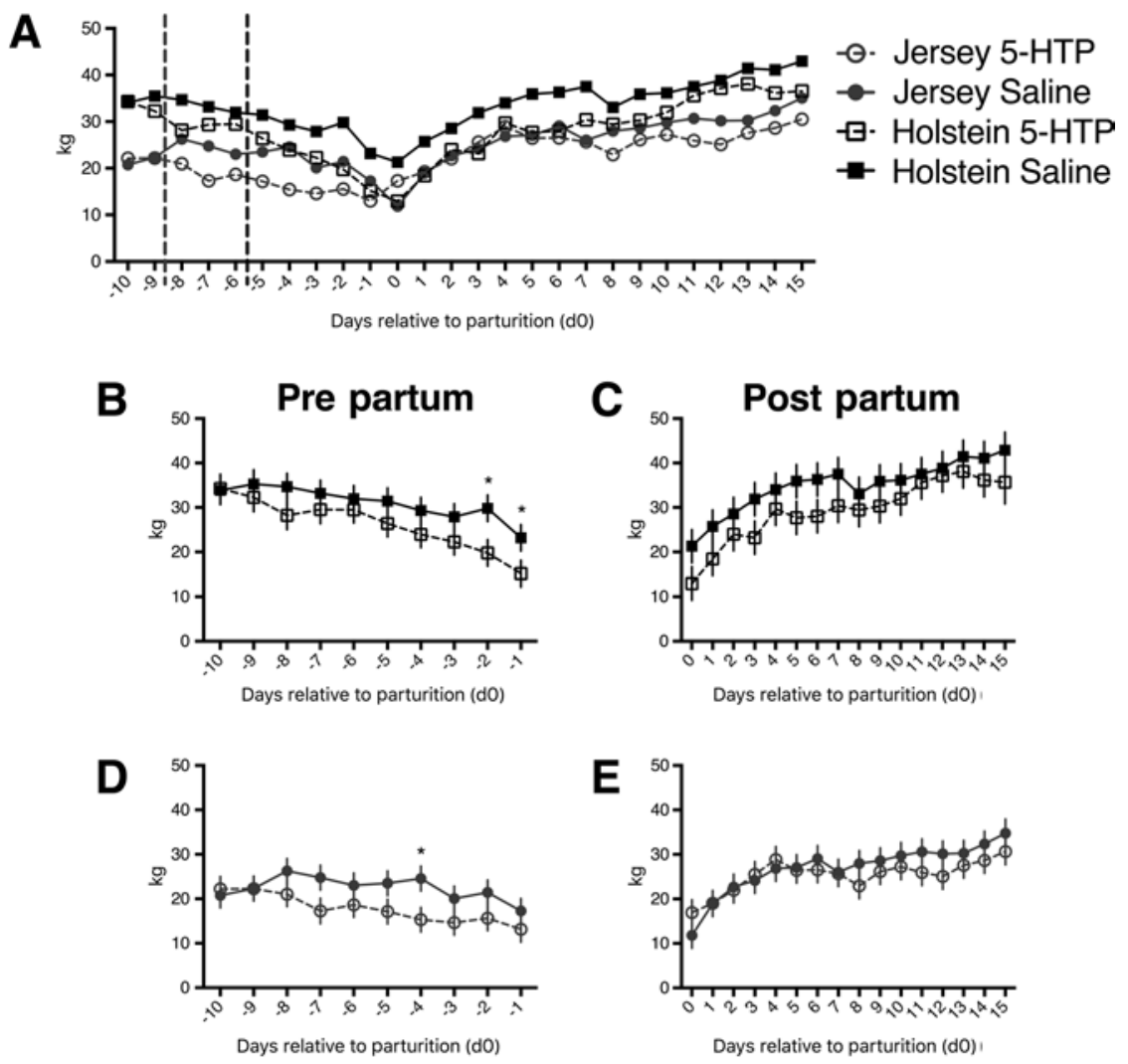

\section{Figure 1}

Feed intake (kg DM) by multiparous Holstein cows and multiparous Jersey cows administered prepartum daily i.v. infusions of $1 \mathrm{~L}$ saline or $1 \mathrm{~L}$ $1.0 \mathrm{mg} / \mathrm{kg}$ bodyweight of 5-hyroxy-L-tryptophan (5-HTP) reconstituted in saline. Final treatment groups were saline-infused Holsteins $(n=6)$, 5-HTP-infused Holsteins $(n=6)$, saline-infused Jerseys $(n=6)$, and 5-HTP-infused Jerseys $(n=6)$. (A) Effect of the interaction of treatment, breed, and day relative to parturition (day 0 ). On average, Holstein cows were infused for $5.67 \pm 0.78$ days (black vertical dotted line) and Jersey cows were infused for $8.67 \pm 1.53$ days (gray vertical dotted line). Least squares difference $($ LSD $)=8.40 \mathrm{~kg}$. (B) Effect of 5-HTP treatment within Holstein cows prepartum. (C) Effect of 5-HTP treatment within Holstein cows postpartum. (D) Effect of treatment within Jersey cows prepartum. (E) Effect of treatment within Jersey cows postpartum. (F) Effect of breed within all saline-infused cows prepartum. (G) Effect of breed within all saline-infused cows postpartum. (H) Effect of breed within all 5-HTP-infused cows prepartum. (I) Effect of breed within all 5-HTP cows infused postpartum. Stars indicate statistical difference between group means $\left({ }^{*} 0.05<P<0.01\right.$, $* * 0.01<P<0.001)$. All values are reported as LS mean \pm S.E.M.

where H 5-HTP cows gave more milk than J 5-HTP cows for all days of lactation $(P \leq 0.04)$ except the day of parturition $(P>0.05)$ and day 1 of lactation $(P>0.05$; Fig. 2 E) .

\section{Infusion of 5-HTP increases circulating serotonin}

Circulating serotonin concentrations were dynamic in response to infusion prepartum and postpartum, dependent on the breed and treatment (Fig. 3A). The baseline values for each treatment group used as a covariate were $1076 \pm 260,1251 \pm 485,1224 \pm 453$, and $978 \pm 489 \mathrm{ng} / \mathrm{mL}$ for H CON, H 5 -HTP, J CON, and J 5-HTP, respectively. Serotonin was elevated in H 5-HTP cows relative to $\mathrm{H}$ CON cows prepartum $(P=0.01)$ and more specifically for the 5 days before parturition $(P \leq 0.04$; Fig. 3B). H 5-HTP cows also had elevated circulating serotonin compared with $\mathrm{H}$ CON cows on the day of parturition $(P=0.002)$ and on day 1 of lactation $(P=0.04$; Fig. 3C). Prepartum, DRP tended to have an effect on serotonin $(P=0.08)$, while this effect was more

Published by Bioscientifica Ltd 
A

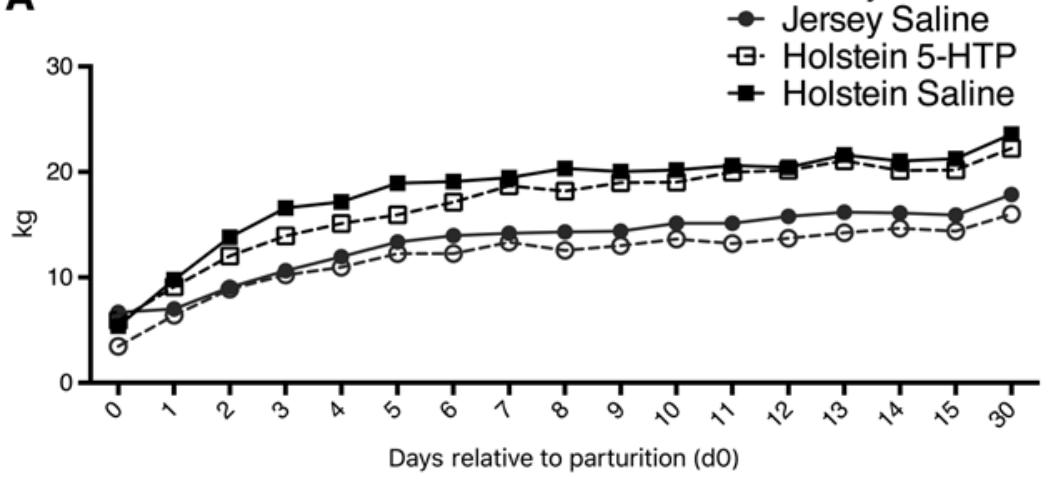

B

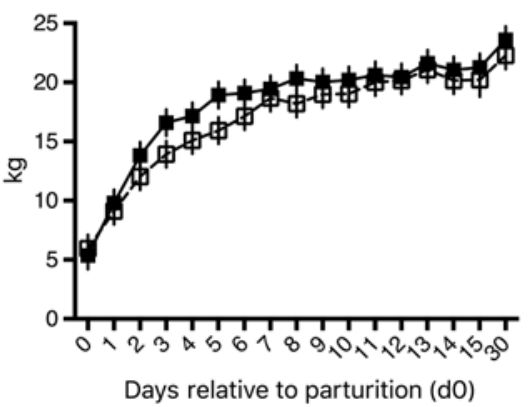

D

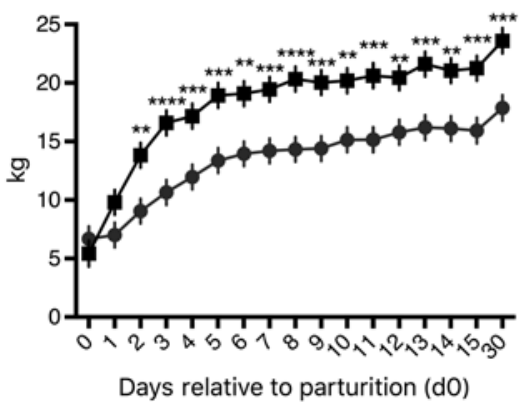

C

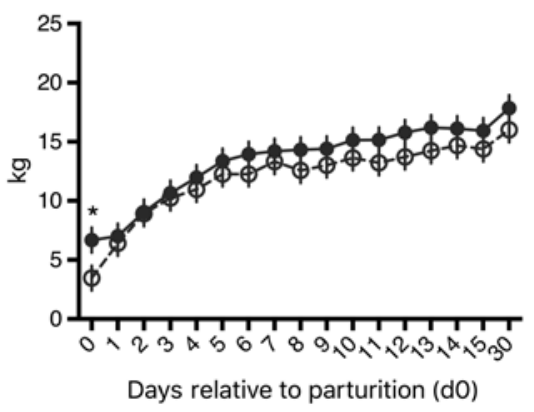

E

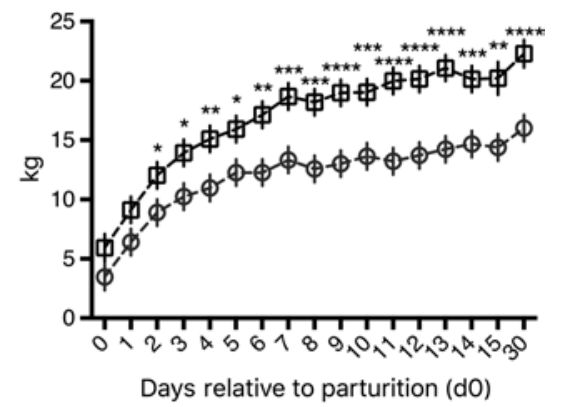

Figure 2

Postpartum milk yield by multiparous Holstein cows and multiparous Jersey cows administered prepartum daily i.v. infusions of $1 \mathrm{~L}$ saline or $1 \mathrm{~L}$ $1.0 \mathrm{mg} / \mathrm{kg}$ bodyweight of 5-hyroxy-L-tryptophan (5-HTP) reconstituted in saline. Final treatment groups were saline-infused Holsteins $(n=6)$, 5-HTP-infused Holsteins $(n=6)$, saline-infused Jerseys $(n=6)$, and 5-HTP-infused Jerseys $(n=6)$. (A) Effect of the interaction of treatment, breed, and day relative to parturition (day 0 ). On average, Holstein cows were infused for $5.67 \pm 0.78$ days (black vertical dotted line) and Jersey cows were infused for $8.67 \pm 1.53$ days (gray vertical dotted line). Least squares difference $($ LSD $)=2.86 \mathrm{~kg}$. (B) Effect of 5-HTP treatment within Holstein cows. (C) Effect of 5-HTP treatment within Jersey cows. (D) Effect of breed within all saline-infused cows. (E) Effect of breed within all 5-HTP infused cows. Stars indicate statistical difference between group means $\left({ }^{*} 0.05<P<0.01,{ }^{*} * 0.01<P<0.001\right.$, $* * * 0.001<P<0.0001, * * * * P<0.0001)$. All values are reported as LS mean \pm S.E.M. pronounced postpartum $(P=0.01)$. In Jersey cows prepartum, J 5-HTP tended to have more serotonin than J CON cows overall $(P=0.09)$ and specifically on 2 days before parturition $(P=0.003$; Fig. 3D). On the day of parturition, J 5-HTP had higher serotonin than J CON cows $(P=0.05)$, and they also tended to have higher serotonin on day 1 of lactation $(P=0.08)$ and on day 12 of lactation $(P=0.002)$. Both prepartum $(P<0.0001)$ and postpartum $(P=0.07)$, DRP had an effect on serotonin concentrations in Jersey cows (Fig. 3E). Among all cows infused with saline, there were no breed or DRP effects prepartum $(P>0.05$; Fig. 3F), but there was an effect of DRP postpartum $(P=0.04)$ and a breed by DRP interaction postpartum $(P=0.006)$, with $\mathrm{J}$ CON demonstrating higher circulating serotonin concentrations than $\mathrm{H} C O N$ on
(C) 2016 Society for Endocrinology Printed in Great Britain days $6(P=0.002)$ and 14 postpartum $(P<0.0001$; Fig. $3 G)$. While there were no treatment effects prepartum within all cows infused with 5-HTP, DRP did have an effect $(P=0.004)$ with serotonin concentrations elevating as the day of parturition approached (Fig. 3H). Postpartum, DRP had an effect on serotonin concentrations $(P=0.01)$, and J 5-HTP cows had higher serotonin on the day of parturition $(P=0.05)$ and on day 12 of lactation $(P=0.009)$ compared with H 5-HTP cows (Fig. 3I).

\section{Circulating prolactin concentrations are not affected by 5-HTP infusion}

In addition to the 10 days prepartum, prolactin was analyzed for only 3 days postpartum, as prolactin is most

Published by Bioscientifica Ltd. 

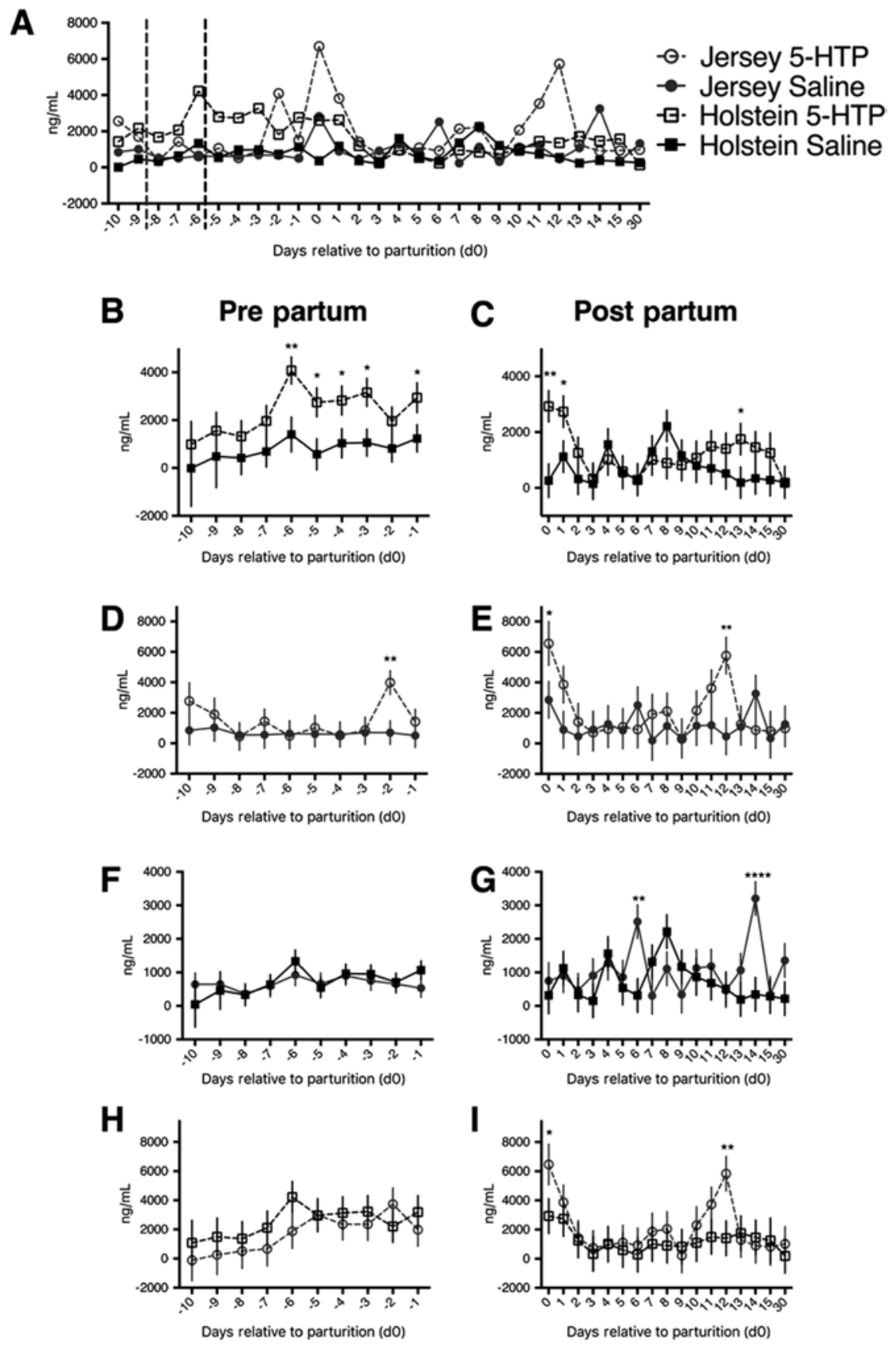

\section{Figure 3}

Circulating serum serotonin concentrations of multiparous Holstein cows and multiparous Jersey cows administered prepartum daily i.v. infusions of $1 \mathrm{~L}$ saline or $1 \mathrm{~L} 1.0 \mathrm{mg} / \mathrm{kg}$ bodyweight of 5-hyroxy-L-tryptophan (5-HTP) reconstituted in saline. Final treatment groups were saline-infused Holstein ( $n=6), 5$-HTP-infused Holstein $(n=6)$, saline-infused Jersey $(n=6)$, and 5-HTP-infused Jersey cows $(n=6)$. (A) Effect of the interaction of treatment, breed, and day relative to parturition (day 0). On average, Holstein cows were infused for $5.67 \pm 0.78$ days (black vertical dotted line) and Jersey cows were infused for $8.67 \pm 1.53$ days (gray vertical dotted line). Least squares difference $(L S D)=2740.9 \mathrm{ng} / \mathrm{mL}$. (B) Effect of 5-HTP treatment within Holstein cows prepartum. (C) Effect of 5-HTP treatment within Holstein cows postpartum. (D) Effect of treatment within Jersey cows prepartum. (E) Effect of treatment within Jersey cows postpartum. (F) Effect of breed within all saline-infused cows prepartum.

(G) Effect of breed within all saline-infused cows postpartum. (H) Effect of breed within all 5-HTP-infused cows prepartum. (I) Effect of breed within all 5-HTP-infused cows infused postpartum. Stars indicate statistical difference between group means. Stars indicate statistical difference between group means $(* 0.05<P<0.01$, $* * 0.01<P<0.001, * * * * P<0.0001)$. All values are reported as LS mean \pm S.E.M. crucial for the onset of lactogenesis and does not change dramatically following the first few days of lactation. There was a marked increase in prolactin during lactogenesis and the characteristic decrease in prolactin concentrations following parturition, as described previously (Horseman 1999). There was no treatment effect, treatment by DRP interaction, breed by DRP interaction, or treatment by breed by DRP interaction with respect to circulating prolactin concentrations $(P>0.05$; Fig. 4$)$. The DRP affected circulating prolactin $(P<0.0001)$, and there was a trend for the difference due to an interaction between treatment and breed $(P=0.09)$.

\section{Infusion of 5-HTP affects circulating calcium dynamics}

Circulating total calcium dynamics were responsive to infusion of 5-HTP (Fig. 5A). The baseline values for each treatment group used as a covariate were $2.73 \pm 0.10$, $2.64 \pm 0.12,2.44 \pm 0.12$, and $2.57 \pm 0.15 \mathrm{mM}$ for $\mathrm{H} \mathrm{CON}$, H 5-HTP, J CON, and J 5-HTP, respectively. One H CON,

Published by Bioscientifica Ltd. 


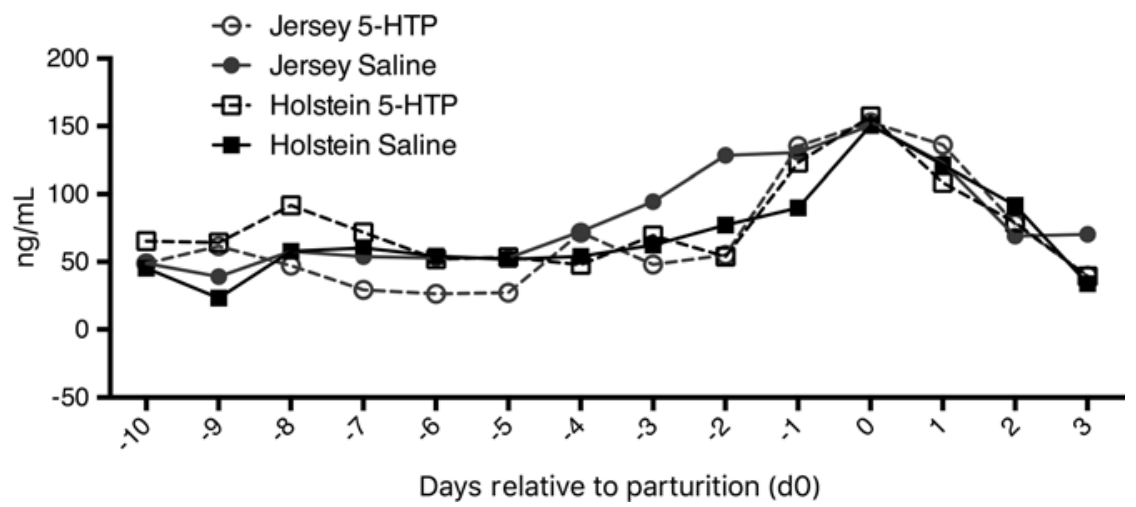

\section{Figure 4}

Effect of the interaction of treatment, breed, and day relative to parturition (day 0 ) on circulating plasma prolactin concentrations of multiparous Holstein cows and multiparous Jersey cows administered prepartum daily i.v. infusions of $1 \mathrm{~L}$ saline or $1 \mathrm{~L} 1.0 \mathrm{mg} / \mathrm{kg}$ of 5-hyroxy-L-tryptophan (5-HTP) reconstituted in saline. Final treatment groups were saline-infused Holstein $(n=6), 5$-HTP-infused Holstein $(n=6)$, saline-infused Jersey $(n=6)$, and 5 -HTP-infused Jersey cows $(n=6)$. On average, Holstein cows were infused for $5.67 \pm 0.78$ days (black vertical dotted line) and Jersey cows were infused for $8.67 \pm 1.53$ days (gray vertical dotted line). Least squares difference $(L S D)=46.3 \mathrm{ng} / \mathrm{mL}$. Statistical significance is set at $P<0.05$. All values are reported as LS mean \pm S.E.M.

three H 5-HTP, six J CON, and four J 5-HTP had at least one calcium concentration below normocalcemic levels (below $2.0 \mathrm{mM}$ ) within 1 day prepartum through the critical 48-h window postpartum. As mentioned previously, two H CON, two J CON, and one J 5-HTP cow required i.v. calcium administration after parturition due to clinical symptoms of hypocalcemia. Within treated cows, the nadir following parturition but pretreatment with i.v. calcium was $1.62 \pm 0.21 \mathrm{mM}$, which is approaching the diagnostic cutoff for clinical hypocalcemia of less than $1.4 \mathrm{mM}$. The nadir for total circulating calcium concentrations in H CON, H 5-HTP, and J CON cows was on day 1 of lactation $(1.99,2.12$, and $1.99 \mathrm{mM}$, respectively). Interestingly, J 5-HTP cows reached their nadir for total circulating calcium concentrations 1 day before all other treatment groups, on the day of parturition $(2.05 \mathrm{mM})$. Prepartum, there was an effect of DRP on calcium concentrations in Holstein cows $(P=0.002)$, with a characteristic decline that is typically seen at parturition (Moore et al. 2015; Fig. 5B). Postpartum, H 5-HTP cows tended to have overall higher calcium concentrations $(P=0.07)$, with DRP having an effect $(P<0.0001)$, and significantly higher calcium concentrations than $\mathrm{H}$ CON cows on the day of parturition $(P=0.04)$, and on days $6,8,11$, and 12 of lactation $(P \leq 0.03$; Fig. $5 C)$. Within Jersey cows, there was a treatment by DRP interaction prepartum $(P=0.02)$, and an effect of DRP alone $(P=0.01)$. In the 3 days prepartum, J 5-HTP cows had significantly lower circulating calcium concentrations than J CON cows $(P \leq 0.03)$, and this effect continued until the day of parturition, when J 5-HTP tended to have lower total calcium concentrations than J CON ( $P=0.09$; Fig. 5D). Postpartum, J CON cows had higher calcium concentrations than J 5-HTP cows $(P=0.04)$ and circulating calcium concentrations elevated as the lactation progressed ( $P=0.001$; Fig. $5 \mathrm{E}$ ).

Among saline-infused cows prepartum, DRP had an effect $(P=0.001)$, and there was an interaction of breed with DRP, with J CON cows having higher total calcium than H CON cows ( $P=0.04$; Fig. 5F). J CON cows continued to have higher calcium concentrations than $\mathrm{H}$ CON cows on the day of parturition $(P=0.01)$ and on days 3 and 13 of lactation $(P \leq 0.05)$. Additionally, although there was no overall breed effect or breed by DRP interaction, circulating total calcium levels elevated as the lactation progressed among saline-infused cows $(P<0.0001$; Fig. 5G). With respect to 5-HTP-infused cows, both DRP $(P=0.05)$ and the interaction of DRP with breed had an effect on calcium concentrations prepartum $(P=0.05)$, and on the 3 days immediately before parturition, H 5-HTP had higher calcium concentrations than J 5-HTP $(P \leq 0.03$; Fig. $5 \mathrm{H})$. Postpartum, there was an effect of DRP $(P=0.003)$ and an interaction of breed with DRP $(P=0.01)$ within 5 -HTP cows, with H 5-HTP having higher calcium concentrations than J 5-HTP on day 6 through 15 postpartum, excluding day 7 ( $P \leq 0.05$; Fig. 5 I).

\section{Infusion of 5-HTP increases milk calcium concentrations in Jersey cows, but not in Holstein cows}

Infusion of 5-HTP elevated milk calcium concentrations in each breed differently over the course of lactation (Fig. 6A). Within Holstein cows, H CON had higher overall

Published by Bioscientifica Ltd. 

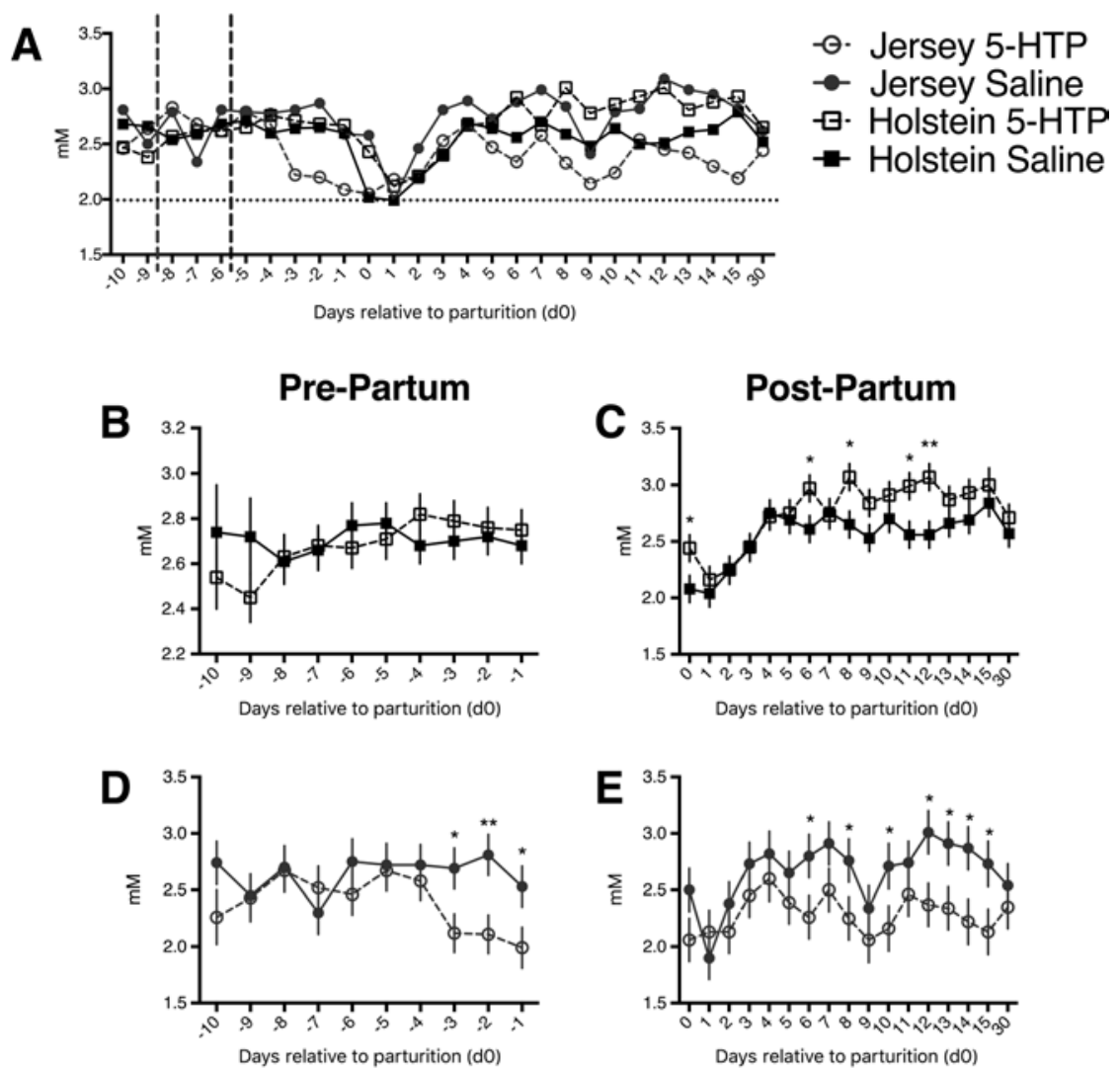

\begin{abstract}
Figure 5
Circulating serum total calcium concentrations of multiparous Holstein cows and multiparous Jersey cows administered prepartum daily i.v. infusions of $1 \mathrm{~L}$ saline or $1 \mathrm{~L} 1.0 \mathrm{mg} / \mathrm{kg}$ bodyweight of 5-hyroxy-L-tryptophan (5-HTP) reconstituted in saline. Final treatment groups were saline-infused Holstein $(n=6), 5$-HTP-infused Holstein $(n=6)$, saline-infused Jersey $(n=6)$, and 5-HTP-infused Jersey cows $(n=6)$. (A) Effect of the interaction of treatment, breed, and day relative to parturition (day 0). On average, Holstein cows were infused for $5.67 \pm 0.78$ days (black vertical dotted line) and Jersey cows were infused for $8.67 \pm 1.53$ days (gray vertical dotted line). Least squares difference $(L S D)=0.454 \mathrm{mM}$. (B) Effect of 5-HTP treatment within Holstein cows prepartum. (C) Effect of 5-HTP treatment within Holstein cows postpartum. (D) Effect of treatment within Jersey cows prepartum. (E) Effect of treatment within Jersey cows postpartum. (F) Effect of breed within all saline infused cows prepartum.

(G) Effect of breed within all saline infused cows postpartum. (H) Effect of breed within all 5-HTP infused cows prepartum. (I) Effect of breed within all 5-HTP cows infused postpartum. Stars indicate statistical difference between group means $\left({ }^{*} 0.05<P<0.01, * * 0.01<P<0.001\right)$. All values are reported as LS mean \pm S.E.M.
\end{abstract}

milk calcium concentrations than H 5-HTP $(P=0.03)$, particularly on the day of parturition $(P=0.01)$ and day 1 of lactation $(P=0.002)$, and milk calcium concentrations declined throughout the lactation $(P<0.0001$; Fig. 6A). By contrast, J 5-HTP cows had higher milk calcium concentrations than J CON cows when taking DRP into consideration $(P=0.03)$. While J 5-HTP only had numerically higher milk calcium concentrations on the day of parturition $(2.10 \pm 0.18$ vs $1.87 \pm 0.23 \mathrm{mg}$ calcium $/ \mathrm{mL}$ milk for J 5-HTP and J CON, respectively) and day 1 of lactation, on day 30 of lactation, J 5-HTP had significantly higher milk calcium concentrations than J CON $(P=0.03)$. Similar to Holsteins, milk calcium concentrations declined throughout the lactation $(P=0.01)$ in Jerseys (Fig. 6B).

Saline-infused Jerseys had higher milk calcium concentrations than $\mathrm{H}$ CON overall in interaction with 
A

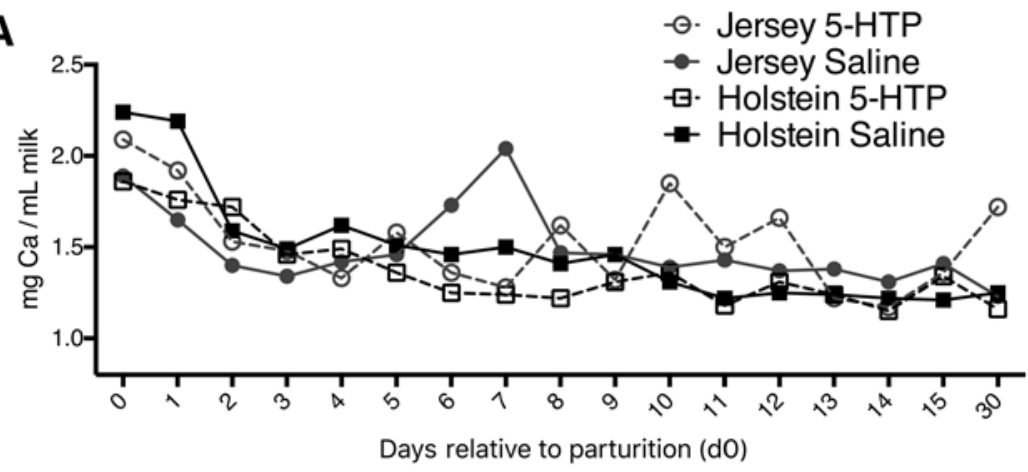

B

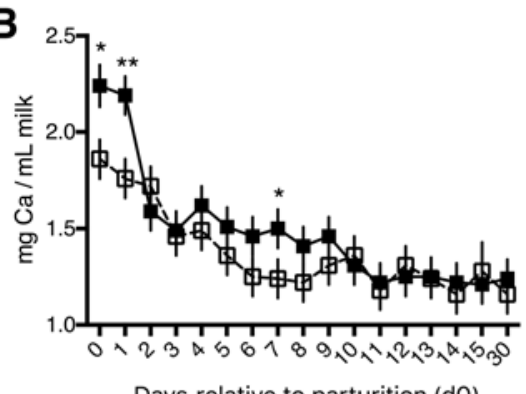

Days relative to parturition (d0)

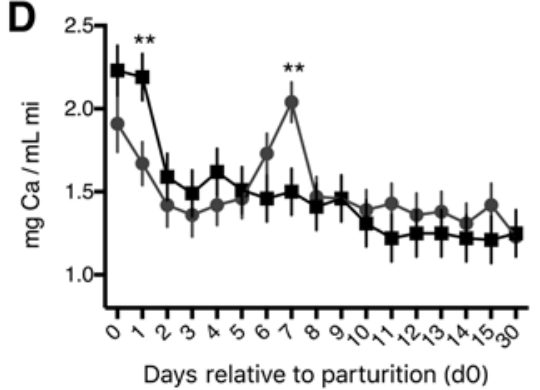

C

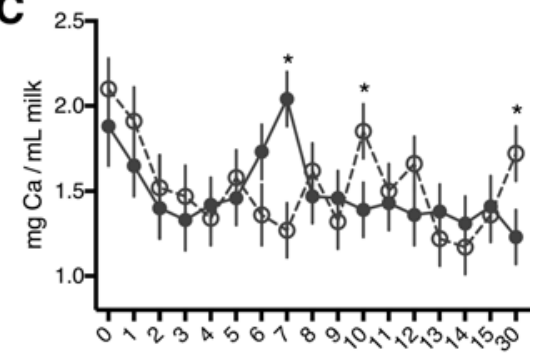

Days relative to parturition (d0)

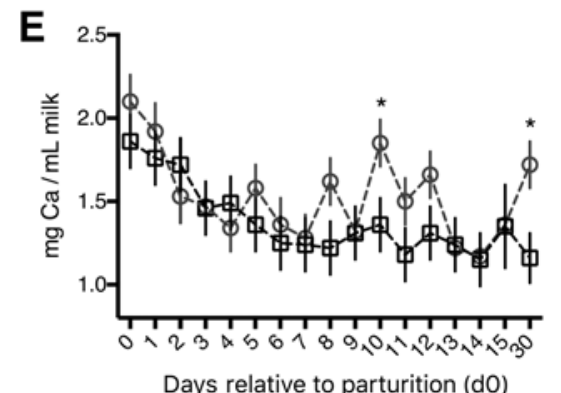

Figure 6

Postpartum total milk calcium concentrations of multiparous Holstein cows and multiparous Jersey cows administered prepartum daily i.v. infusions of $1 \mathrm{~L}$ saline or $1 \mathrm{~L} 1.0 \mathrm{mg} / \mathrm{kg}$ of 5 -hyroxy-Ltryptophan (5-HTP) reconstituted in saline. Final treatment groups were saline-infused Holstein $(n=6), 5$-HTP-infused Holstein $(n=6)$, salineinfused Jersey $(n=6)$, and 5-HTP-infused Jersey cows $(n=6)$. (A) Effect of the interaction of treatment, breed, and day relative to parturition (day 0). On average, Holstein cows were infused for $5.67 \pm 0.78$ days (black vertical dotted line) and Jersey cows were infused for $8.67 \pm 1.53$ days (gray vertical dotted line). Least squares difference (LSD) $=0.403 \mathrm{mg} \mathrm{Ca} / \mathrm{mL}$ milk. (B) Effect of 5-HTP treatment within Holstein cows.

(C) Effect of 5-HTP treatment within Jersey cows. (D) Effect of breed within all saline-infused cows. (E) Effect of breed within all 5-HTP-infused cows. Stars indicate statistical difference between group means $\left({ }^{*} 0.05<P<0.01, * * 0.01<P<0.001\right)$. All values are reported as LS means \pm S.E.M.
DRP $(P=0.04)$, but there was no breed effect alone $(P>0.05)$. On day 1 of lactation, $\mathrm{H} C O N$ had higher milk calcium concentrations than J CON $(P=0.006)$, while $\mathrm{J}$ CON had higher milk calcium concentrations than H CON on day 7 of lactation $(P=0.003$; Fig. 6C). Within all cows infused with 5-HTP, J 5-HTP had higher milk calcium concentrations than $\mathrm{H}$ 5-HTP $(P=0.004)$, particularly on days $10(P=0.02)$ and $30(P=0.01)$ of lactation (Fig. 6D).

\section{Urine DPD is affected by 5-HTP treatment, and dependent on breed}

Holsteins infused with 5-HTP had higher urine DPD levels prepartum $(P=0.002)$ and there was an interaction of treatment with DRP $(P=0.01)$, but no effect of DRP alone $(P>0.05)$. Postpartum, H 5-HTP cows had higher urine DPD concentrations on the day of parturition $(P=0.05)$, and urine DPD concentrations elevated in both treatments throughout the lactation $(P<0.0001$; Fig. 7B). Similarly, in Jersey cows, J 5-HTP cows tended to have higher urine DPD concentrations than $\mathrm{J} C \mathrm{CON}$ cows prepartum in interaction with DRP $(P=0.08)$, and DPD concentrations were dynamic over time $(P=0.0004)$. Postpartum, there was an effect of DRP on urine DPD concentrations $(P<0.0001)$ with DPDs elevating until day 8 and then falling in both treatment groups, but no treatment effect or treatment by DRP interaction $(P>0.05$; Fig. 7C).

Among saline-infused cows, J CON cows tended to have higher DPD concentrations than $\mathrm{H}$ CON cows $(P=0.09)$ prepartum, significantly so 2 days before parturition $(P<0.03)$. Postpartum, J CON cows had higher urine DPD concentrations than $\mathrm{H}$ CON cows $(P=0.01)$, significantly so on days 8 and 9 (when DPD concentrations peaked $(P<0.0001))$ and on days 11 and 12 of lactation $(P \leq 0.05)$ (Fig. 7D). Prepartum among 


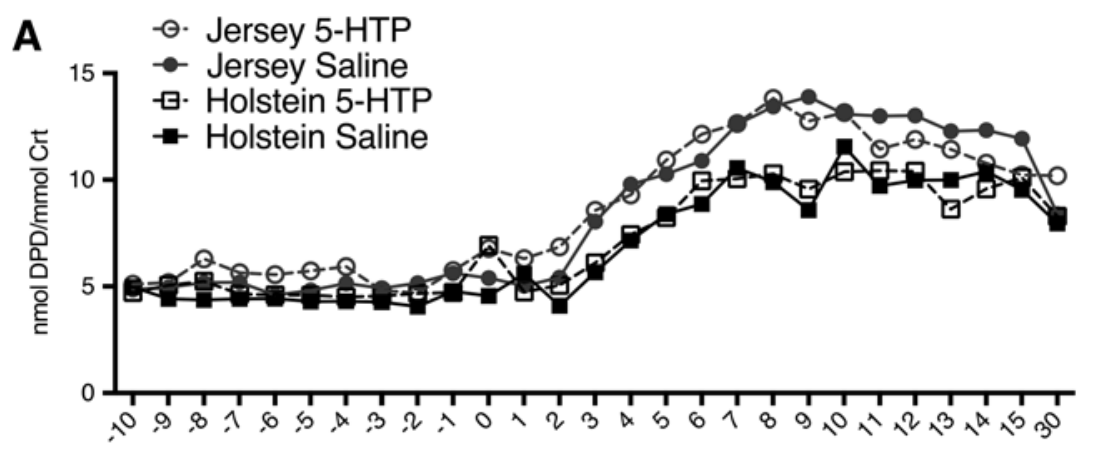

Days relative to parturition (d0)

B

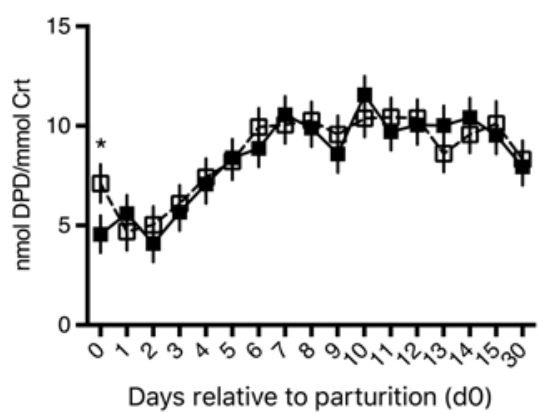

D

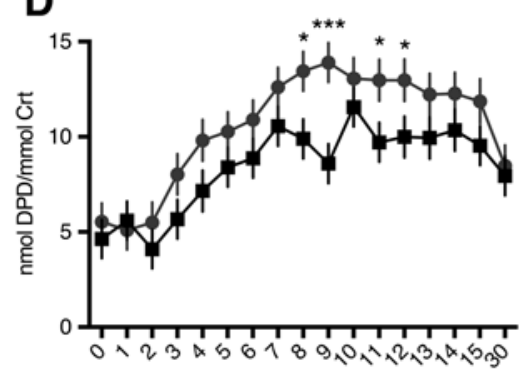

Days relative to parturition (d0)

C

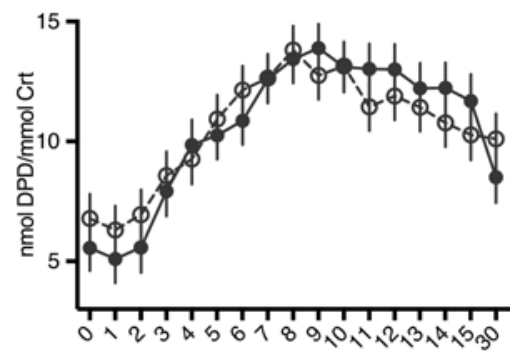

Days relative to parturition ( $\mathrm{d} 0$ )

E

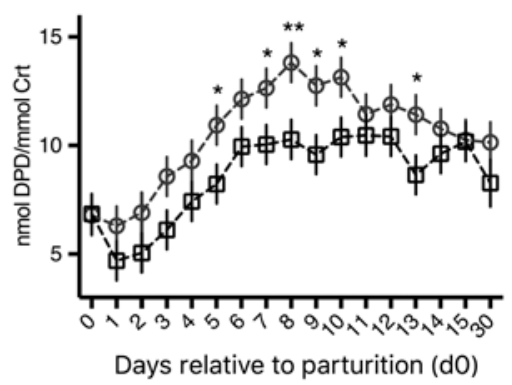

\section{Figure 7}

Urine deoxypyridinoline (DPD) concentrations of multiparous Holstein cows and multiparous Jersey cows administered prepartum daily i.v. infusions of $1 \mathrm{~L}$ saline or $1 \mathrm{~L} 1.0 \mathrm{mg} / \mathrm{kg}$ of 5-hyroxy-L-tryptophan (5-HTP) reconstituted in saline. Final treatment groups were salineinfused Holstein $(n=6), 5$-HTP-infused Holstein $(n=6)$, saline-infused Jersey $(n=6)$, and 5-HTP-infused Jersey cows $(n=6)$. (A) Effect of the interaction of treatment, breed, and day relative to parturition (day 0 ). On average, Holstein cows were infused for $5.67 \pm 0.78$ days (black vertical dotted line) and Jersey cows were infused for $8.67 \pm 1.53$ days (gray vertical dotted line). Least squares difference $(L S D)=2.05 \mathrm{nmol} D P D / \mathrm{mmol}$ creatinine. (B) Effect of 5-HTP treatment within Holstein cows. (C) Effect of 5-HTP treatment within Jersey cows. (D) Effect of breed within all saline-infused cows. (E) Effect of breed within all 5-HTP-infused cows. Stars indicate statistical difference between group means $\left({ }^{*} 0.05<P<0.01\right.$, $* * 0.01<P<0.001, * * * 0.001<P<0.0001)$. All values are reported as LS mean \pm S.E.M.
5-HTP infused cows, there was no treatment effect $(P>0.05)$, but DPD concentrations were dynamic with DRP $(P<0.0001)$. Postpartum, J 5-HTP cows had higher urine DPD concentrations than H 5-HTP cows $(P=0.03)$, specifically on days $5,7,8,9,10$, and 13 of lactation $(P \leq 0.04)$, and DPD concentrations peaked on day 8 and then declined throughout lactation $(P<0.0001)$ (Fig. 7E).

\section{Discussion}

During lactation, the mammary gland is predominately regulated in an autocrine-paracrine fashion by local rather than by systemic factors (Weaver \& Hernandez 2016). One major regulator of mammary gland function is the monoamine serotonin, which has particular importance for maintenance of calcium homeostasis in both rodents and dairy cows (Matsuda et al. 2004, Hernandez et al. 2012b, Laporta et al. 2014a, 2015). During the transition from pregnancy to lactation, dairy cows are susceptible to calcium-related disorders, specifically periparturient hypocalcemia (Goff 2008, DeGaris \& Lean 2009). Previous work from our lab has demonstrated that serotonin positively regulates calcium homeostasis in late-lactation dairy cows (Laporta et al. 2015). To date, however, no research has been reported on the role of serotonin in modulating calcium homeostasis in dairy cows transitioning from pregnancy to lactation. In addition, although Jersey cows are known to have as much as a $2.25 \times$ increased incidence of hypocalcemia (Lean et al. 2006), only limited research efforts have focused on the etiology of hypocalcemia in different 
breeds of dairy cows. Our hypothesis in this study was that treatment of dairy cows with 5-HTP, the immediate precursor to serotonin, during the prepartum phase would lead to an improvement in calcium status during the postpartum period. Confirmation of this improvement in calcium status would support the use of 5-HTP as a therapeutic prevention strategy against the development of hypocalcemia. We also hypothesized that Jersey cows would be more responsive to 5-HTP treatment. The data herein demonstrate that i.v. infusion of 5-HTP in the week before parturition had positive effects on calcium status in both Jersey and Holstein cows postpartum. The benefits were unique to and dependent on the breed of cattle.

Although we had previously established a safe dose at which to administer 5-HTP to late-lactation dairy cows, it was unclear whether transition cows would respond differently, given that the weeks surrounding parturition are associated with reduced immune function, feed intake, and negative energy balance, leading to increased risk of metabolic disease (LeBlanc 2010). To evaluate the acute effects of 5-HTP administration on the health of peripartum cows, we monitored heart rate, respiratory rate, and rectal temperature throughout the course of all infusion periods. None of these parameters were affected by the 5-HTP infusion. It is well established that as much as $90 \%$ of serotonin is synthesized in the gut (Kim \& Khan 2014) and that exogenous administration of serotonin potently stimulates gastrointestinal motility (Spencer 2015). This was evident in the frequency of defecation and severity of stool looseness in our cows, both of which were increased throughout the course of 5-HTP infusion. This phenomenon was not dependent on the breed of dairy cow. None of the cows in the current experiment exhibited visible signs of dehydration as a result of the increased bowel motility. We concluded, therefore, that 5-HTP administration did not have an acute impact on transition cow health.

We next assured that 5-HTP infusion was not affecting crucial factors such as feed intake and milk yield, as these would be significant deterrents to the use of 5-HTP for commercial production. The characteristic decrease in feed intake was detected in both breeds at the time of parturition. Jersey cows consumed less than Holstein cows overall, as is typical when comparing these two breeds (Rastani et al. 2001). Treatment with 5-HTP tended to affect feed intake prepartum, which could be related to the increased gut motility produced as a result of the prepartum 5-HTP infusion. Jersey cows infused with 5-HTP had more depressed feed intake compared with J CON cows than H 5-HTP cows relative to H CON cows.
This may be attributed to the number of infusion days, as Jersey cows were infused for more days overall than Holstein cows, thereby having an accumulating effect on gut motility over time. However, the length of infusion between breeds was not significant. Additionally, it is unlikely that energy status was affected given that there was no difference in postpartum feed intake as a result of treatment in either breed. Holstein cows produced more milk than Jersey cows, again characteristic of these breeds (Rastani et al. 2001, Prendiville et al. 2009). Only on the day of parturition in Jersey cows did 5-HTP treatment result in decreased milk yield, with milk yield equalizing by day 1 of lactation. Colostrum formation (colostrogenesis) is assumed to begin approximately 15-20 days before parturition (Collier et al. 2012). Colostrum quantity and quality are absolutely essential to calf health; therefore, the lack of any detrimental effects on colostrum yield following infusion of 5-HTP is significant. Further studies should be conducted to examine the impact of 5-HTP on the quality of colostrum.

In peripartum cows, serotonin concentrations can be quite variable. In a previous study performed in our laboratory, serotonin concentrations varied approximately $1000 \mathrm{ng} / \mathrm{mL}$ from the 3 days prepartum to the 3 days postpartum (Moore et al. 2015). In the 6 days prepartum in this study, serotonin concentrations were significantly elevated in both H 5-HTP cows relative to H CON cows, and J 5-HTP cows had elevated serotonin 2 days before parturition and on the day of parturition compared with J CON cows. This implies that, despite natural variability between individuals, 5-HTP treatment prepartum elevates circulating serotonin concentrations in both Holstein and Jersey cows. Additionally, based on prepartum circulating serotonin concentrations, Jersey cows apparently respond more gradually to treatment with 5-HTP than Holstein cows. This gradual increase in circulating serotonin corresponds to the gradual decline in circulating total calcium concentrations in J 5-HTP cows that occurs prepartum, which suggests that serotonin is stimulating the transient hypocalcemia necessary to liberate calcium from bone before parturition (Wysolmerski 2010). Interestingly, serotonin concentrations remained elevated in both breeds relative to their respective CON groups on the day of parturition and day 1 of lactation, and were only again elevated later in the lactation, beginning at around day 10. Finally, it is of note that Moore and coworkers (2015) reported a decrease in circulating serotonin levels on the days leading up to and immediately following parturition. However, our data show a different pattern in the 5-HTP treatment groups, as both groups had elevated

Published by Bioscientifica Ltd. 
serotonin concentrations on the day of parturition. This is not surprising, given that in Moore and coworkers (2015), no treatments were applied. Furthermore, this suggests that 5-HTP treatment was able to maintain higher circulating serotonin concentrations around the time of parturition.

Notably, there was no difference in prolactin concentrations during the pre- or postpartum periods in either breed or in response to 5-HTP treatment. Prolactin is a potent lactogenic hormone in most species, but, until recently, there was still debate as to its importance in ruminants. Studies by Lacasse and coworkers (2012) have demonstrated that prolactin is galactopoietic in dairy cows, and that it is largely regulated in the local, mammary gland environment. At a neuronal level, administration of serotonin (Kamberi et al. 1971) or 5-HTP (Lu \& Meites 1973) into the brain of rats provoked an increase in circulating prolactin concentrations. In the rodent mammary gland, prolactin activates the Janus kinase 5/signal transducer and activator of transcription 5 (Jak/STAT5) pathway, which regulates milk protein synthesis (Horseman 1999). When administered to a human mammary epithelial cell line, exogenous serotonin downregulates this pathway, resulting in decreased $\beta$-casein expression (Chiba et al. 2014). Our results indicate that exogenous administration of 5-HTP likely does not affect circulating prolactin concentrations in peripartum dairy cows. Instead, it appears that serotonin and prolactin are functioning through largely independent pathways during this time period in the overall circulation. However, given that both serotonin and prolactin have known autocrine and paracrine actions on the mammary gland (Weaver \& Hernandez 2016), further studies should consider the relationship of these hormones peripartum at the glandular and cellular levels.

Administration of serotonin prepartum affected calcium homeostasis during both pre- and postpartum periods, depending on the breed. Given the 54\% incidence of subclinical hypocalcemia in multiparous herds (Reinhardt et al. 2011), there is still a gap in terms of strategies to prevent hypocalcemia. One current tactic is to feed anionic salts prepartum. This practice reduced the incidence of clinical hypocalcemia (Charbonneau et al. 2006), but responses were less conclusive in the alleviation of subclinical hypocalcemia (Moore et al. 2000, Ramos-Nieves et al. 2009). Cows used in this research experiment were fed a low-energy, high-fiber diet that included straw and corn silage, which are generally lower in potassium content than alternate feed ingredients. The reduced potassium content helps to control DCAD without anionic salt addition (Drackley \& Guretzky 2007). For this reason, the DCAD mineral content of approximately $+9.9 \mathrm{mEq} / 100 \mathrm{~g}$ was not unexpected for the current diets. Further studies are required to evaluate the impact of serotonin in combination with different feeding strategies, particularly diets which provide a negative DCAD (Goff 2008, DeGaris \& Lean 2009). Given that 5-HTP administration in this trial affected circulating calcium concentrations without a negative DCAD diet, it would be useful and interesting to see how calcium changes postpartum are affected by a combination of these two preventative strategies.

While the experiment was not designed to evaluate disease incidence postpartum, all health events were recorded. Of the 24 cows enrolled in our study, two H CON, two H 5-HTP, three J CON, and two J 5-HTP were treated for ketosis. With respect to mastitis, one $\mathrm{H} \mathrm{CON}$, three H 5-HTP, four J CON, and one J 5-HTP had mastitis. Only one H 5-HTP had a retained placenta. Finally, two H CON, two J CON, and one J 5-HTP required i.v. calcium administration after parturition due to clinical symptoms of hypocalcemia. Therefore, with respect to hypocalcemia, only 1 out of 12 -HTP-infused cows required therapeutic intervention relative to 4 out of 12 of saline-infused cows. Clinical hypocalcemia is a debilitating disease that negatively impacts the cow's welfare, as it often results in the cow's inability to stand due to severe muscle tremors (Goff 2008). The current observation that only one cow treated with 5-HTP required intervention for clinical symptoms of hypocalcemia is consistent with the potential for 5-HTP as a therapeutic tool during prepartum periods. However, there was no marked difference in ketosis incidence and mastitis occurrence seemed to be dependent on breed, with less J 5-HTP developing mastitis than J CON, but more H 5-HTP developing mastitis than $\mathrm{H}$ CON. Clearly, more experiments with a greater number of animals need to be conducted in this area to confirm our findings.

Although the intent of this study was to examine the effect of 5-HTP administration prepartum on postpartum calcium homeostasis, several insights were revealed from the examination of prepartum total calcium concentrations in serum. In Jersey cows, the most striking result of 5-HTP administration was the more gradual decline in calcium concentrations prepartum. In a previous study, we had noted that circulating calcium concentrations decreased in response to acute 5-HTP infusion in late lactation Holstein cows (Laporta et al. 2015). On our infusion days immediately prepartum, circulating calcium levels did not appear to decline in H 5-HTP cows relative to H CON cows,

Published by Bioscientifica Ltd 
but there was a gradual decline in circulating calcium over the 3 days prepartum in J 5-HTP cows compared with all other cows. In all other treatment groups, there was a drop in circulating calcium concentrations, either on the day before or the day of parturition. Although they reached a similar nadir $(2.05 \mathrm{mM})$, J 5-HTP cows began to display a gradual decline in circulating calcium concentrations prepartum. This is interesting because it is possible that the Jersey cows treated with 5-HTP are initiating a transient decrease in circulating calcium concentrations prepartum, in order to initiate an earlier recovery of circulating calcium concentrations at the time of parturition.

In addition, as all the other treatment groups showed a decrease in circulating calcium concentrations over the first day of lactation, the J 5-HTP cows began to recover from their nadir within the first day postpartum. This recovery is significant for two reasons: (1) increasing circulating calcium is important to overall health, and (2) a transient hypocalcemia must be established to activate bone resorption mechanisms which release calcium during lactation (VanHouten et al. 2004, Ardeshirpour et al. 2006). Calcium is mobilized from bone during lactation as a result of mammary-derived PTHrP actions on the bone to increase osteoclastic resorption (Wysolmerski 2010). Serotonin is crucial to this system, as a stimulator of PTHrP release from the mammary gland. Additionally, PTHrP increases activity of mammary calcium pumps and transporters to transfer the resorbed bone calcium into milk and prevent a negative feedback of elevated circulating calcium from a downregulation of PTHrP release (Hernandez et al. 2012b, Laporta et al. 2013a, Horseman \& Hernandez 2014). The release of mammary PTHrP, therefore, depends on initiation of a transient hypocalcemia (VanHouten et al. 2004, Ardeshirpour et al. 2006). Our results infer that, in Jersey cows, 5-HTP administration potentially stimulates this transient hypocalcemia during the prepartum period. The prepartum decline stimulated by exogenous 5-HTP in Jersey cows induces a cascade of signaling pathways to increase bone resorption and calcium release for secretion into milk and allows an earlier recovery in postpartum circulating calcium concentrations relative to salineinfused Jersey cows. Indeed, in J 5-HTP cows, there was numerically more calcium in milk than in J CON cows on the day of and day after parturition, inferring that 5-HTP may aid in the initiation of bone resorption as a source of calcium for milk. In Jersey cows, we propose that exogenous 5-HTP administration provokes both an earlier and more gradual decline in circulating total calcium concentrations, as opposed to a sudden, severe drop in calcium concentrations of saline-treated animals relying solely on endogenous signals. This gradual adaptation and transient hypocalcemia may facilitate an earlier recovery in circulating calcium concentrations around parturition, potentially before the significant demand for milk production depletes circulating calcium stores leading to the negative cascade of events triggered by hypocalcemia. However, this hypothesis needs to be explored more thoroughly.

Given the gradual prepartum decline in total serum calcium, J 5-HTP cows may avoid hypocalcemia at parturition and more steadily regulate their calcium homeostasis postpartum. Compared with saline-infused Holstein cows, H 5-HTP cows tended to have elevated calcium concentrations postpartum, significantly so on the day of parturition. Postpartum, J 5-HTP cows had lower circulating calcium concentrations than J CON cows, but none of the 5-HTP cows had serum calcium concentrations below the threshold for designation of subclinical hypocalcemia $(1.4-2.0 \mathrm{mM} / \mathrm{L}$, Reinhardt et al. 2011). The lower circulating calcium concentrations in J 5-HTP cows appear to be consistent with an increased movement of calcium into milk on the day of and the day after parturition, although the milk calcium concentrations become quite variable in Jersey cows throughout the lactation. In Holstein cows, the mechanism appears to be different than Jersey cows, as $\mathrm{H}$ CON cows had higher milk calcium concentrations than H 5-HTP cows on the day of parturition and day 1 of lactation. Importantly, our results do not include the flux of calcium which also occurs in renal and intestinal regulation of calcium homeostasis in dairy cows (Goff 2008). It is possible that the decreased circulating calcium concentrations in J 5-HTP cows compared with all other treatment groups may be explained by increased excretion of calcium or by more calcium being utilized in organs such as the mammary gland, intestine, and muscle.

Although renal and intestinal calcium flux was not evaluated in the current study, assessments were made on the impact of 5-HTP administration on bone resorption. Deoxypyridinoline is a pyridinium cross-link that provides structure and strength to type 1 collagen in bone. The cross-link peptide is released by osteoclast resorption of bone (Rubinacci et al. 1999). Interestingly, DPD concentrations have been shown to be elevated in primiparous cows when compared with multiparous cows (Kamiya et al. 2005), implying that decreased bone turnover activity may contribute to the higher incidence of hypocalcemia as cows age. The higher risk of developing

Published by Bioscientifica Ltd 
hypocalcemia in Jersey cows compared with other breeds is well established, but limited research efforts have attempted to elucidate the physiological reason for their predisposition (Oetzel et al. 1988, Goff et al. 1995). We proposed that bone resorption may play an important role in establishing the differences between Holstein and Jersey cows for calcium regulation postpartum. We further proposed that 5-HTP may affect bone resorption in dairy cows. Urine concentrations of DPD were measured as a marker of bone calcium resorption. A reduction in DPD concentrations would reflect a decrease in bone calcium resorption. Jersey cows had overall higher concentrations of DPD in their urine postpartum than Holstein cows, although J 5-HTP cows had similar DPD concentrations relative to J CON cows. One important exception to the elevation of DPD concentrations in Jersey cows compared with Holstein cows is on the day of parturition, when H 5-HTP cows and J 5-HTP cows have very similar DPD concentrations in their urine $(P=0.89 ; 6.93 \pm 0.79$ vs $6.78 \pm 0.79 \mathrm{nmol} \mathrm{DPD} / \mathrm{mmol}$ creatinine in $\mathrm{H} 5$-HTP and J 5-HTP, respectively), with $\mathrm{H}$ 5-HTP cows peaking over $\mathrm{H}$ CON cows on this day. Given the role of DPD as a marker of osteoclastic bone resorption (Kamiya et al. 2005), our data imply that Jersey cows are mobilizing more bone than Holsteins starting on about day 3 postpartum, although it is important to note that we do not know the initial concentrations of DPD in Holstein cow versus Jersey cow bone. Additionally, given the spike in urine DPD concentrations on the day of parturition in H 5-HTP cows, it appears that 5-HTP infusion may provoke significant bone turnover at the start of lactation in Holstein cows, subsequently stimulating the overall elevated levels of circulating calcium in $\mathrm{H}$ 5-HTP cows relative to $\mathrm{H}$ CON cows postpartum. The missing piece of this mechanistic puzzle is the circulating plasma PTHrP concentration, as previous correlations between milk and plasma PTHrP and calcium in cows have been made (Onda et al. 2006, Moore et al. 2015). Although we attempted to evaluate our samples for PTHrP, we were unable to measure PTHrP in all the cows in our experiments, due to some cows being below detection limits. This prohibited us from making any statistical comparisons regarding this hormone in this particular experiment. Comparing Holstein cows to Jersey cows in other respects, however, provides further insights into the potential mechanisms behind serotonin's role in the prevention of hypocalcemia.

Our data demonstrate the stark contrast in the regulation of calcium between Jersey cows and Holstein cows. Postpartum, J 5-HTP cows had numerically lower circulating calcium concentrations than J CON cows, but no differences were detected in urine DPD levels, and milk calcium concentrations were quite variable. Furthermore, calcium concentrations were above the threshold for subclinical hypocalcemia, regardless of treatment. Importantly, by day 30 of lactation, blood calcium concentrations were similar between J CON cows and J 5-HTP cows, and milk calcium was elevated in J 5-HTP cows relative to J CON cows, suggesting that the prepartum transient hypocalcemia and subsequent postpartum low blood calcium levels in response to serotonin may support a more stable calcium axis further along in lactation. By contrast, on the day of parturition, H 5-HTP cows had higher DPD concentrations in their urine and higher circulating calcium than H CON cows throughout lactation, inferring increased bone turnover. The lower circulating calcium in H CON cows compared with $\mathrm{H}$ 5-HTP cows may be explained by the high concentrations of calcium in milk in the $\mathrm{H}$ CON cows on the day of parturition and day 1 of lactation, suggesting that 5-HTP may not be stimulating movement of calcium into milk in the Holsteins, but the calcium may be used for a variety of other intracellular or homeostatic processes. Also noteworthy was the observation that $\mathrm{H}$ CON cows had higher milk calcium concentrations than J CON cows for the first few days of lactation, but this breed difference disappeared with addition of the 5-HTP, as the H 5-HTP cows had lower milk calcium than J 5-HTP cows. Although it has previously been reported that Jersey cows had approximately 36\% higher milk calcium than Holstein cows (Czerniewicz et al. 2006), this was not evident in our experiment until later in the lactation, when it appears that J CON and J 5-HTP begin to secrete more calcium in milk than their Holstein counterparts. Importantly, Czerniewicz and coworkers (2006) evaluated milk samples over a 6-month period, whereas our data were collected over a much more limited time of only 2 weeks postpartum. Our data implies that, although 5-HTP stimulated increased bone turnover on the day of parturition, H 5-HTP cows did not secrete as much calcium into their milk as J 5-HTP cows. Apparently, the H 5-HTP cows instead conserved calcium in their circulation as evidenced by their elevated serum calcium levels. By contrast, H CON cows had significantly higher amounts of calcium in their milk relative to J CON cows, and had lower blood calcium levels postpartum.

Taken together, this evidence demonstrates that Jersey and Holstein cows reflect different postpartum calcium axes, but both respond dynamically to 5-HTP administration prepartum. Overall, elevation of circulating

Published by Bioscientifica Ltd. 
serotonin levels prepartum by 5-HTP administration induced a transient hypocalcemia prepartum in the J 5-HTP cows that resulted in more bone turnover than in the H 5-HTP cows, with the exception of the day of parturition, emphasizing the breed-dependent effects of 5-HTP on bone mobilization. More milk calcium was detected in milk from J 5-HTP cows than J CON cows on the days immediately after parturition, although only numerically so. By contrast, 5-HTP treatment in Holstein cows appeared to increase circulating calcium concentrations postpartum and increase urine DPD concentrations at parturition, although saline-infused Holstein cows have increased milk calcium concentrations. We predict that J 5-HTP cows would have higher circulating PTHrP concentrations than H 5-HTP cows as well, as PTHrP is responsible for stimulating bone turnover in response to a transient hypocalcemia during lactation. In summary, we propose that treatment of dairy cows with 5-HTP during the prepartum period may provide benefits for postpartum calcium homeostasis in both Jersey and Holstein cows, although through different mechanisms. Further studies focused on hypocalcemia should pay particular attention to the breed, as our data demonstrate that even untreated Jerseys and Holstein cows have dramatically different mechanisms of calcium homeostasis around the time of parturition. We can state confidently, however, that 5-HTP warrants further investigation as a preventative strategy for the prevention of subclinical and clinical hypocalcemia in dairy cows.

\section{Declaration of interest}

The authors declare that there is no conflict of interest that could be perceived as prejudicing the impartiality of the research reported.

\section{Funding}

The reported study was supported by the USDA-HATCH Formula Fund, grant 142-PRJ74RD, as well as funding provided by the Wisconsin Consortium for Extension and Research in Agriculture and Natural Resources (CERANR) and Graduate School funding provided by the University of WisconsinMadison.

\section{Author contribution statement}

S R W and L L H designed, wrote, and analyzed the experiment. A P P, E LE, and $S A N$ assisted in carrying out the animal trial and laboratory analyses. T L P carried out laboratory analyses. P M C helped design and perform the statistical analysis. M S A, T D C, and R M B contributed to the writing of the manuscript and consulted on experimental design, diet design and analysis, and laboratory procedures.

\section{Acknowledgments}

The authors would like to acknowledge the staff at the Dairy Cattle Center for the maintenance and care of the dairy cows used in this trial. This material is based upon work supported by the National Science Foundation Graduate Research Fellowship Program under Grant No. DGE-1256259. Any opinions, findings, and conclusions or recommendations expressed in this material are those of the author(s) and do not necessarily reflect the views of the National Science Foundation. Support was also provided by the Graduate School and the Office of the Vice Chancellor for Research and Graduate Education at the University of Wisconsin-Madison with funding from the Wisconsin Alumni Research Foundation.

\section{References}

Ardeshirpour L, Dann P, Pollak M, Wysolmerski J \& VanHouten J 2006 The calcium-sensing receptor regulates PTHrP production and calcium transport in the lactating mammary gland. Bone 38 787-793. (doi:10.1016/j.bone.2005.11.009)

Bruckmaier RM, Schams D \& Blum JW 1992 Aetiology of disturbed milk ejection in parturient primiparous cows. Journal of Dairy Research $\mathbf{5 9}$ 479-489. (doi:10.1017/S002202990002714X)

Chapinal N, Carson M, Duffield TF, Capel M, Godden S, Overton M, Santos JE \& LeBlanc SJ 2011 The association of serum metabolites with clinical disease during the transition period. Journal of Dairy Science 94 4897-4903. (doi:10.3168/jds.2010-4075)

Charbonneau E, Pellerin D \& Oetzel GR 2006 Impact of lowering dietary cation-anion difference in nonlacting dairy cows: a meta-analysis. Journal of Dairy Science 89 537-548. (doi:10.3168/jds.S00220302(06)72116-6)

Chiba T, Kimura S, Takahashi K, Morimoto Y, Sanbe A, Ueda H \& Kudo K 2014 Serotonin suppresses $\beta$-casein expression via inhibition of the signal transducer and activator of transcription 5 (STAT5) protein phosphorylation in human mammary epithelial cells MCF-12A. Biological and Pharmaceutical Bulletin 37 1336-1340. (doi:10.1248/ bpb.b14-00273)

Collier RJ, Annen-Dawson EL \& Pezeshki A 2012 Effects of continuous lactation and short dry periods on mammary function and animal health. Animal 6 403-414. (doi:10.1017/S1751731111002461)

Czerniewicz M, Kiełczewska K \& Kruk A 2006 Comparison of some physiochemical properties of milk from Holstein-Friesian and Jersey cows. Polish Journal of Food and Nutrition Sciences 15 61-64.

DeGaris PJ \& Lean IJ 2009 Milk fever in dairy cows: a review of pathophysiology and control principles. Veterinary Journal 176 58-69. (doi:10.1016/j.tvjl.2007.12.029)

Drackley JK \& Guretzky NAJ 2007 Controlled energy diets for dry cows. In Proceedings of the Western Dairy Management Conference, 7-9 March 2007, pp1-11. Reno, NV, USA: WDMC. (available at: http://wdmc. org/2007/drackley.pdf)

Goff JP 2008 The monitoring, prevention, and treatment of milk fever and subclinical hypocalcemia in dairy cows. Veterinary Journal 176 50-57. (doi:10.1016/j.tvjl.2007.12.020)

Goff JP, Reinhardt TA \& Horst RL 1995 Milk fever and dietary cationanion balance effects on concentration of vitamin $\mathrm{D}$ receptor in tissue of periparturient dairy cows. Journal of Dairy Science $\mathbf{7 8}$ 2388-2394. (doi:10.3168/jds.S0022-0302(95)76867-9)

Hannon J \& Hoyer D 2008 Molecular biology of 5-HT receptors. Behavioural Brain Research 195 198-213. (doi:10.1016/j. bbr.2008.03.020)

Hernandez LL, Grayson BE, Yadav E, Seeley RJ \& Horseman ND $2012 a$ High fat diet alters lactation outcomes: possible involvement of inflammatory and serotonergic pathways. PLOS ONE 732598. (doi:10.1371/journal.pone.0032598)

Hernandez LL, Gregerson KA \& Horseman ND 2012b Mammary gland serotonin regulates parathyroid hormone-related protein and other

Published by Bioscientifica Ltd. 
bone-related signals. American Journal of Physiology: Endocrinology, and Metabolism 302 1009-1015. (doi:10.1152/ajpendo.00666.2011)

Horseman ND 1999 Prolactin and mammary gland development. Journal of Mammary Gland Biology and Neoplasia 4 79-88. (doi:10.102 3/A:1018708704335)

Horseman ND \& Hernandez LL 2014 New concepts of breast cell communication to bone. Trends in Endocrinology \& Metabolism 25 34-41. (doi:10.1016/j.tem.2013.08.004)

Kamberi IA, Mical RS \& Porter JC 1971 Effects of melatonin and serotonin on the release of FSH and prolactin. Endocrinology $\mathbf{8 8}$ 1288-1293. (doi:10.1210/endo-88-6-1288)

Kessler EC, Bruckmaier RM \& Gross JJ 2014 Milk production during the colostral period is not related to later lactational performance in dairy cows. Journal of Dairy Science 97 2186-2192. (doi:10.3168/jds.20137573)

Kamiya Y, Kamiya M, Tanaka M \& Shioya S 2005 Effects of calcium intake and parity on plasma minerals and bone turnover around parturition. Animal Science Journal 76 325-330. (doi:10.1111/j.17400929.2005.00271.x)

Kim JJ \& Khan WI 2014 5-HT7 receptor signaling: improved therapeutic strategy in gut disorders. Frontiers in Behavioral Neuroscience 11396. (doi:10.3389/fnbeh.2014.00396)

Kimura K, Reinhardt TA \& Goff JP 2006 Parturition and hypocalcemia blunts calcium signals in immune cells of dairy cattle. Journal of Dairy Science 89 2588-2595. (doi:10.3168/jds.S00220302(06)72335-9)

Lacasse P, Lollivier V, Dessauge F, Bruckmaier RM, Ollier S \& Boutinaud M 2012 New developments on the galactopoietic role of prolactin in dairy ruminants. Domestic Animal Endocrinology 43 154-160. (doi:10.1016/j.domaniend.2011.12.007)

Laporta J, Peters TL, Weaver SR, Merriman KE \& Hernandez LL 2013a Feeding 5-hydroxy-l-tryptophan during the transition from pregnancy to lactation increases calcium mobilization from bone in rats. Domestic Animal Endocrinology 44 176-184. (doi:10.1016/j.domaniend.2013.01.005)

Laporta J, Moore SA, Peters MW, Peters TL \& Hernandez LL 2013b Short communication: circulating serotonin (5-HT) concentrations on day 1 of lactation as a potential predictor of transition-related disorders. Journal of Dairy Science 96 5146-5150. (doi:10.3168/jds.2013-6718)

Laporta J, Keil KP, Vezina CM \& Hernandez LL 2014a Peripheral serotonin regulates maternal calcium trafficking in mammary epithelial cells during lactation in mice. PLOS ONE 9 e110190. (doi:10.1371/journal. pone.0110190)

Laporta J, Keil KP, Weaver SR, Cronick CM, Prichard AP, Crenshaw TD, Heyne GW, Vezina CM, Lipinski RJ \& Hernandez LL 2014b Serotonin regulates calcium homeostasis in lactation by epigenetic activation of hedgehog signaling. Molecular Endocrinology 28 1866-1874. (doi:10.1210/me.2014-1204)

Laporta J, Moore SAE, Weaver SR, Cronick CM, Olsen M, Prichard AP, Schnell BP, Crenshaw TD, Peñagaricano F, Bruckmaier RM, et al. 2015 Increasing serotonin concentrations alter calcium and energy metabolism in dairy cows. Journal of Endocrinology 226 43-55. (doi:10.1530/JOE-14-0693)

Lean IJ, DeGaris PJ, McNeil DM \& Block E 2006 Hypocalcemia in dairy cows: meta-analysis and dietary cation anion difference theory revisited. Journal of Dairy Science 89 669-684. (doi:10.3168/jds.S00220302(06) 72130-0)

LeBlanc S 2010 Monitoring the metabolic health of dairy cattle in the transition period. Journal of Reproduction and Development 56 S29-S35.

Lu KH \& Meites J 1973 Effects of serotonin precursors and melatonin on serum prolactin release in rats. Endocrinology 93 152-155. (doi:10.1210/endo-93-1-152)

Martín-Tereso J \& Verstegen MWA 2011 A novel model to explain dietary factors affecting hypocalcemia in dairy cattle. Nutrition Research Reviews 24 228-243. (doi:10.1017/S0954422411000126)
Martinez N, Risco CA, Lima FS, Bisinotto RS, Greco LF, Ribeiro ES, Maunsell F, Galvão K \& Santos JE 2012 Evaluation of peripartal calcium status, energetic profile, and neutrophil function in dairy cows at low or high risk of developing uterine disease. Journal of Dairy Science 95 7158-7172. (doi:10.3168/jds.2012-5812)

Martinez N, Sinedino LD, Bisinotto RD, Ribeiro ES, Gomes GC, Lima FS, Greco LF, Risco CA, Galvão KN, Taylor-Rodriguez D, et al. 2014 Effect of induced subclinical hypocalcemia on physiological responses and neutrophil function in dairy cows. Journal of Dairy Science $\mathbf{9 7}$ 874-887.

Matsuda M, Imaoka T, Vomachka AJ, Gudelsky GA, Hou Z, Mistry M, Bailey JP, Nieport KM, Walther DJ, Bader M, et al. 2004 Serotonin regulates mammary gland development via an autocrineparacrine loop. Developmental Cell 6 193-203. (doi:10.1016/S15345807(04)00022-X)

McArt JAA \& Oetzel GR 2015 A stochastic estimate of the economic impact of oral calcium supplementation in postparturient dairy cows. Journal of Dairy Science 98 1-11. (doi:10.3168/jds.2014-8433)

Moore SJ, VandeHaar MJ, Sharma BK, Pilbeam TE, Beede DK, Buckholtz HF, Liesman JS, Horst RL \& Goff JP 2000 Effects of altering dietary cation-anion difference on calcium and energy metabolism in peripartum cows. Journal of Dairy Science 83 2095-2104. (doi:10.3168/ jds.S0022-0302(00)75091-0)

Moore SA, Laporta J, Crenshaw TD \& Hernandez LL 2015 Patterns of circulating serotonin and related metabolites in multiparous dairy cows in the peripartum period. Journal of Dairy Science 98 3754-3765. (doi:10.3168/jds.2014-8841)

Oetzel GR, Olson JD, Curtis CR \& Fettman MJ 1988 Ammonium chloride and ammonium sulfate for prevention of parturient paresis in dairy cows. Journal of Dairy Science 71 3302-3309. (doi:10.3168/jds.S00220302(88)79935-X)

Onda K, Sato A, Yamaguchi M, Matsuki N, Ono K \& Wada Y 2006 Parathyroid hormone-related protein (PTHrP) and Ca levels in the milk of lactating cows. Journal of Veterinary Medical Science $\mathbf{6 8}$ 709-713. (doi:10.1292/jvms.68.709)

Prendiville R, Pierce KM \& Buckley F 2009 An evaluation of production efficiencies among lactating Holstein-Friesian, Jersey, and Jersey $\times$ Holstein-Friesian cows at pasture. Journal of Dairy Science 92 6176-6185. (doi:10.3168/jds.2009-2292)

Ramos-Nieves JM, Thering BJ, Waldron MR, Jardon PW \& Overton TR 2009 Effects of anion supplementation to low-potassium prepartum diets on micromineral status and performance of periparturient dairy cows. Journal of Dairy Science 92 5677-5691. (doi:10.3168/jds.20092378)

Rastani RR, Andrew SM, Zinn SA \& Sniffen CJ 2001 Body composition and estimated tissue energy balance in Jersey and Holstein cows during early lactation. Journal of Dairy Science 84 1201-1209. (doi:10.3168/jds.S0022-0302(01)74581-X)

Reinhardt TA, Lippolis JD, McCluskey BJ, Goff JP \& Horst RL 2011 Prevalence of subclinical hypocalcemia in dairy herds. Veterinary Journal 188 122-124. (doi:10.1016/j.tvj1.2010.03.025)

Rubinacci A, Melzi R, Zampino M, Soldarini A \& Villa I 1999 Total and free deoxypyridinoline after acute osteoclast activity inhibition. Clinical Chemistry 45 1510-1516.

Spencer NJ 2015 Constitutively active 5-HT receptors: an explanation of how 5-HT antagonists inhibit gut motility in species where 5-HT is not an enteric neurotransmitter? Frontiers in Cellular Neuroscience 9 487. (doi:10.3389/fncel.2015.00487)

Stull MA, Pai V, Vomachka AJ, Marshall AM, Jacob GA \& Horseman ND 2007 Mammary gland homeostasis employs serotonergic regulation of epithelial tight junctions. PNAS $\mathbf{1 0 4}$ 16708-16718. (doi:10.1073/ pnas.0708136104)

VanHouten J, Dann P, McGeoch G, Brown EM, Krapcho K, Neville KM \& Wysolmerski JJ 2004 The calcium-sensing receptor regulates mammary gland parathyroid hormone-related protein production http://joe.endocrinology-journals.org

DOI: $10.1530 / J O E-16-0038$
(C) 2016 Society for Endocrinology Printed in Great Britain 
and calcium transport. Journal of Clinical Investigation 113 598-608. (doi:10.1172/JCI200418776)

Wang L, Erlandsen H, Haavik J, Knappskog P \& Stevens RC 2002 Threedimensional structure of human tryptophan hydroxylase and its implications for the biosynthesis of the neurotransmitters serotonin and melatonin. Biochemistry 41 12569-12574. (doi:10.1021/bi026561f)

Weaver SR \& Hernandez LL 2016 Autocrine-paracrine regulation of the mammary gland. Journal of Dairy Science 99 842-853. (doi:10.3168/ jds.2015-9828)
Wysolmerski JJ 2010 Interactions between breast, bone, and brain regulate mineral and skeletal metabolism during lactation. Annals of the New York Academy of Sciences 1192 161-169. (doi:10.1111/j.17496632.2009.05249.x)

Wysolmerski JJ, McCaughern-Carucci JF, Daifotis AG, Broadus AE \& Philbrick WM 1995 Overexpression of parathyroid hormonerelated protein or parathyroid hormone in transgenic mice impairs branching morphogenesis during mammary gland development. Development 121 3539-3547.

Received in final form 9 May 2016

Accepted 23 May 2016
Published by Bioscientifica Ltd. 